\title{
ISOGLOSAS INTERNAS DEL CASTELLANO. EL SISTEMA REFERENCIAL DEL PRONOMBRE ÁTONO DE TERCERA PERSONA
}

\author{
INÉS FERnÁNDEZ-ORDóÑEZ. \\ Universidad Autónoma de Madrid.
}

\section{Presentación.}

Pocos problemas de la sintaxis del español han interesado tanto a los gramáticos y estudiosos de la lengua a lo largo de la historia como la variación en el uso de los pronombres átonos de tercera persona. Ya desde las primeras observaciones de gramáticos de los siglos Xvi y Xvir el mundo castellanohablante peninsular aparece claramente dividido entre aquellos que utilizan los pronombres átonos, $l e, l a$ y $l o$ (y sus plurales), de acuerdo con distinciones funcionales de caso y aquellos que no las respetan y caen en los usos conocidos como leísmo, laísmo y loismo ${ }^{1}$. Sin embargo, la percepción del uso variable de esos pronombres no ha ido acompañada, ni en la época antigua ni

1 La gramática tradicional y normativa entiende por leismo el uso de la forma $l e$ en lugar de lo (o excepcionalmente, la) como pronombre para el complemento directo. Los autores distinguen distintos tipos de leísmo: 1) el de objeto directo (OD) masculino, y dentro de él, el de OD personal, el más frecuente y extendido, y el de OD de cosa, de difusión más reducida; 2) el leísmo plural, menos frecuente que el singular; 3) el leísmo de OD femenino, tanto singular como plural, muy raro; 4) no se encuentra leísmo (salvo contadísimas excepciones) cuando el referente es neutro. El laísmo es uso menos extendido que el leísmo personal, y el loismo, el menos común de todos. El laísmo es el empleo de la en vez de le para el dativo con referente femenino, y tiene una incidencia un poco mayor en el singular que en el plural. El loismo consiste en usar lo en vez de le para el dativo con referente masculino y es más frecuente en el plural que en el singular. Hay que puntualizar que una parte no pequeña de quienes han tratado estas confusiones habla de loísmo para referirse al uso de lo como complemento directo en oposición al leísmo, como uso de $l e$ en la misma función. Así, al hablar de los escritores andaluces o americanos dicen que son loistas porque utilizan el pronombre lo para el complemento directo, denominación que crea desconcierto en torno al contenido del término. 
en tiempos más modernos, de hipótesis que expliquen satisfactoriamente la totalidad de esos fenómenos en su indudable complejidad. Ello se debe, sin duda, a que en el análisis del problema no se ha concedido suficiente importancia a la diversidad de situaciones de uso pronominal existentes en el mundo hispanohablante. Por lo general, se han procurado explicar todos los leísmos, el laísmo y el loísmo, ya se produzcan en España o en América, en un andaluz o en un castellano, en un hablante culto o en uno que no lo es, recurriendo a las mismas teorías, desatendiendo la posibilidad de que la variedad geográfica y social vaya también acompañada de diversidad de explicaciones.

1. Tradicionalmente el leismo en sus diferentes tipos, el laismo y el loísmo se han venido explicando mediante la hipótesis de dos tendencias lingüísticas que actuarian conjunta y contradictoriamente. Ambas fueron percibidas primeramente por gramáticos del siglo xıx, Vicente Salvá y Rufino José Cuervo, y, con matizaciones posteriores, reconocidas por eminentes gramáticos y filólogos contemporáneos como Salvador Fernández Ramírez y Rafael Lapesa ${ }^{2}$ ( $\mathrm{y}$ a través de ellos por la inmensa mayoría de los que se han acercado al problema).

El leísmo para objetos directos masculinos en el singular (tanto de persona como de cosa), el laísmo y el loísmo (con referente neutro o masculino plural) tendrian su origen en la tendencia a crear en castellano un paradigma de los pronombres átonos basado en el de los demostrativos (este-a-o, estos-as), en el que se eliminarían las distinciones de caso a favor de las de género.

Sin embargo, esta tendencia no consigue aclarar otros fenómenos: la mayor difusión y frecuencia del leísmo con objetos directos personales o entes

2 La escuela española de este siglo aborda el análisis de este problema a través de los trabajos de Rufino José Cuervo: las Notas 106 y 121 a la Gramática de la lengua castellana destinada al uso de los americanos [1847-1860] de Andrés Bello, edición y estudio de Ramón Trujillo, Madrid, Arco/Libros, 1988, págs. 931-939, 945-951, y su artículo "Los casos enclíticos y proclíticos del pronombre de tercera persona en castellano", Romania, XXIV, 1895, págs. 95-113 y 219-263. Tanto Salvador Fernández Ramírez (Gramática española. 3.2. El pronombre [1951], volumen preparado por José Polo, Madrid, Arco/Libros, $1987^{2}$, págs. 40-55, y "Un proceso lingǘstico en marcha", Presente y futuro de la lengua española, II, Madrid, OFINES, 1964, págs. 277-285) como Rafael Lapesa ("Sobre los orígenes y evolución del leísmo, laísmo y loísmo", en K. Baldinger (ed.), Festschrift Walther von Wartburg. Tübingen, Max Niemeyer, 1968, págs. 523551) recogen y matizan las ideas de Cuervo, concediendo más importancia que él a la tendencia lingüística, señalada por otros gramáticos, a distinguir las personas (con le) de las cosas (con $l o, l a$ ). Con anterioridad a ellos, ya Hayward Keniston, The Syntax of castilian Prose. The Sixteenth Century, Chicago, The University of Chicago Press, 1937, págs. 63-82, había trabajado también sobre la hipótesis de la distinción entre las personas y las cosas como causa explicativa de estos fenómenos. 
animados que con objetos inanimados: la existencia del leismo plural y del leismo femenino; el hecho de que ni la. las ni lo, los triunfen como formas de dativo. Por ello, se consideró la incidencia de un segundo factor, a saber, la tendencia a distinguir en castellano los entes personales (o mejor, animados) de los no-personales (o inanimados). Ese deseo de distinguir entre lo animado y lo inanimado, distinción, por lo demás, ampliamente arraigada en muchas lenguas indoeuropeas, sería la otra causa originaria del leismo (pero no del laísmo ni del loismo), la cual, contrarrestando la primera tendencia, permitiría comprender los fenómenos antes mencionados.

El complejo cruce de ambas tendencias, la que quería establecer en los pronombres átonos el mismo paradigma que en los demostrativos con la que queria distinguir los objetos animados de los inanimados, aclararia que ninguna de ellas triunfase por completo y que estos usos no hayan logrado desplazar los empleos aparentemente "etimológicos" en las zonas donde tienen lugar las confusiones.

Esta hipótesis encierra, sin embargo, ciertas limitaciones. En primer lugar, el leismo en sus diferentes tipos, el laismo y el loismo se juzgan como fenómenos de variación porcentual sobre el total de ejemplos observados, sin que pueda predecirse qué produce su aparición en cada caso salvo las "tendencias" mencionadas ni se aclare el porqué de la mayor frecuencia de unas confusiones frente a otras. En segundo, se intenta explicar el origen de todos los tipos de confusión leísta, laísta y loísta partiendo de la variación pronominal encontrada en la zona en que se mantienen las distinciones casuales, en vez de examinarlas como sistema autónomo ${ }^{3}$. Si el sistema "etimológico" ofrecia potencialmente las circunstancias necesarias para el leismo, el laismo $\mathrm{y}$ el loismo en todas partes, esta interpretación es incapaz de aclarar por qué el laismo y el loismo se dan exclusivamente en la Península, y limitados a unas áreas, mientras que el leismo aparece mucho más extendido tanto en España como en América. En tercer lugar y relacionado con lo anterior, hay que señalar que no se contempla la posibilidad de que pueda haber diferencias entre los sistemas pronominales empleados en las varias zonas confundidoras ${ }^{4}$. Al agrupar en el estudio estadístico los ejemplos sin segregarlos según

3 Cuervo explica la extensión de $l o$, $l a$ al dativo y de $l e$ al acusativo a partir de ciertas construcciones sintácticas existentes en zona distinguidora (Notas a la Gramática de Bello, págs. 950-951, y "Los casos", págs. 236-243). Lapesa encuentra en algunas de ellas motivos "etimológicos" para el empleo aparentemente anómalo de le, lo y la ("Sobre los orígenes", págs. 535-537). A partir de estos contextos, habría tenido lugar la expansión progresiva y la generalización de las confusiones.

4 Fernández Ramírez era consciente de esta carencia, pero no compartimos su interpretación sobre la imposibilidad de llegar a conclusiones firmes sobre este asunto: “Poco sabemos hoy de la distribución geográfica de unas y otras formas. Ignoramos si existen límites claros entre un leísmo riguroso y un leísmo atenuado dentro de la Península. Todo hace pensar que las diferencias entre las hablas individuales son en este punto innu- 
la procedencia de los hablantes de una u otra zona confundidora, se han distorsionado seguramente los datos ${ }^{5}$. A estas objeciones se suma la de que la hipótesis se elaboró partiendo exclusivamente del análisis de la lengua escrita ${ }^{6}$, probablemente porque se consideraba objetivo prioritario la reconstruc-

merables y que, más que de áreas y de dialectos, cabria hablar aqui de idiolectos", "Un proceso lingüístico", art. cit., pág. 279.

5 Fernández Ramírez intenta distinguir grados de penetración del leísmo según la geografia, pero sólo alcanza a separar a los confundidores de los distinguidores: "Las cifras de empleo máximo de le (uso exclusivo o casi exclusivo) se encuentran en autores naturales de Valladolid (Guillén. Martínez Sierra, Rosa Chacel, F. de Cossío) o de Madrid (Benavente, Gómez de la Serna). El uso etimológico predominante, nunca exclusivo, lo encontramos en autores andaluces (S. J. A. Quintero, J. R. Jiménez, Alarcón) o de otros territorios no leistas o que no conocen la forma le (Cela, gallego; P. Alvarez, zamorano)" (Gramática española, op. cit., págs. 41-42). Sólo Keniston advierte la existencia de un tercer grupo: " $l c$ has become the regular form for the masculine direct object, wheter referring to persons or to things, among writers of Castilian or northern origin, such as the Cardinal Cisneros, Guevara, Sancho de Muñon, the authors of the Abencerraje and the Lazarillo de Tormes, Santa Teresa, Hermosilla, Luis de León, and San Juan de la Cruz. On the other hand, the historical $l o$ is preferred by writers from the east and south of Spain as a direct objetc referring to masculine persons or things, as, for example, the Gran Capitán, Jiménez de Urrea, Juan de Valdés, Francisco Delicado, and Mateo Alemán. Between these extreme leistas and loistas is a group of writers, all of non-castilian origin, who distinguish between the use of $l e$ as a direct object referring to persons and $l o$ as a direct object referring to masculine things; such are Hernán Cortés, Alfonso de Valdés, Lope de Rueda, and Pérez de Hita" (The Syntax, op. cit., página 64). En cuanto al laismo, los recuentos de Fernández Ramírez no le conducen a extraer conclusiones sobre su distribución geográfica (Gramática española, págs. 47-51), aunque algo sobre ésta puede atisbarse en ellos, asi como en los trabajos de Erica C. García, "The Case of Spanish Gender. Referential Strategies in Language Change", Neuphilologische Mitteilungen, LXXXVII, 1986, págs. 165-184 (esp. págs. 172-173), y "Sincronización y desfase del leísmo y laismo". Neuphilologische Mitteilungen, XCIII. 1992, págs. 235-256 (esp. 238-241).

- Además de Cuervo, Keniston, Fernández Ramírez y Lapesa, han trabajado sobre la lengua escrita y la historia del fenómeno a partir de la misma hipótesis fundamental: Jean Louis Benezech, "Remarques sur les pronoms atones de la troisième personne. Léismes, loismes et laismes", Ibérica (Université de Paris-Sorbonne), 1, 1977, págs. 21-44; Juanita Demmer y Leavitt $\mathrm{O}$. Wright, "A frequency study of the third person object pronouns in the Don Quijote", Hispania, XXXI, 1948, págs. 161-162; María Teresa Echenique Elizondo, "Apócope y leísmo en la Primera Crónica General. Notas para una cronología", Studi Ispanici, Giardini editori e stampatore in Pisa, 1979, págs. 43-58, "Sobre pronombres afijos en español antiguo", Neuphilologische Mitteilungen, LXXXI, 1980, págs. 201-207, y "El sistema referencial en español antiguo", RFE, LXI, 1981, págs. 113-157; María del Mar Espejo Muriel, "Laísmo y loísmo en El viaje entretenido de Agustín de Rojas Villandrando", Antiqua et Nova Romania, Estudios lingüísticos y filológicos en honor de José Mondéjar en su sexagesimoquinto aniversario, I, Universidad de Granada, 1993, págs. 109-132; María Jesús López Bobo, "Sobre el leísmo en el Libro de Bucn Amor", Verba, 17, 1990, págs. 343-361, y "Laísmo y loísmo en el Libro de Buen Amor", Epos, VII, 1991, págs. 593-607; Francisco Marcos Marín, "Apócope y leísmo en el castellano medieval. Aproximación cuantitativa", Estudios ofrecidos a $E$. Alarcos Llorach, I, Universidad de Oviedo, 1976, págs. 145-156, y Estudios sobre el pronombre, Madrid, Gredos, 1978; María del Carmen Sanchis Calvo, "Sobre leísmo y apócope del pronombre de tercera persona singular objeto directo", en M. Ariza, J. M." 
ción histórica del fenómeno, sin considerar que desde antiguo el uso de los pronombres ha estado sujeto a valoraciones por parte de la comunidad lingüistica hispanohablante que no siempre son fáciles de evaluar hoy correctamente y que pueden haber influido en los usos de la lengua culta, quizá sobre todo desde los Siglos de Oro?.

2. Aunque parece obvio que todos los leísmos (y el laismo y el loismo) parten de la reorganización de un sistema básico, el llamado "etimológico" (por ajustarse en él el uso pronominal a la distinción funcional, de origen latino en sus formas. entre dativo y acusativo), hoy resulta evidente que el reanálisis de ese sistema no obedece a las mismas causas en todos los territorios hispanohablantes ${ }^{8}$. Deben por ello diferenciarse en la interpretación básicamente tres situaciones distintas: el leismo de las zonas que distinguen el caso pronominal ${ }^{9}$, el leismo (y eventualmente un extraño loísmo) de las

Mendoza, R. Cano, A. Narbona, Actas del II Congreso Internacional de Historia de la Lengua Española, I, Madrid, Pabellón de España, 1992, págs. 805-812. Véanse también infra en la nota 9 los trabajos de Contreras, García Martín y Kany.

7 Cuervo era consciente de ello: "Muy natural es que el le haya adquirido por estas circunstancias [ser uso propio de la corte] cierto aire de cultura y elegancia que le ha granjeado crédito para el lenguaje literario: de donde las personas en la casa y en la calle dicen siempre $l o$, al escribir ponen, con más o menos frecuencia la otra forma, lo mismo que se valen de voces y giros comunes en los libros, pero ajenos del habla familiar. Así, el uso de cada obra no casa siempre con el de la patria del autor, siendo necesario para averiguar el de ésta, o compulsar escritos de distintos autores o verificarlo directamente por el oído" ("Los casos", pág. 104). Esta objeción resulta especialmente acertada para los datos recogidos desde principios del siglo xix, cuando la Real Academia Española comienza su actitud de condena progresiva de todos los empleos confundidores, hasta el momento actual, en que la Gramática académica tan sólo tolera, sin preferirlo, el leismo aplicado a objeto personal masculino en el singular. En cuanto a los datos procedentes de textos medievales, no es menos arriesgado su manejo, ya que en la Edad Media al problema de la valoración social de estos usos se une, en la mayor parte de los casos, el del desconocimiento de la exacta procedencia geográfica de los manuscritos utilizados.

8 Véase Inés Fernández-Ordóñez, "Leísmo, laismo y loismo : estado de la cuestión". en Olga Fernández Soriano (ed.), Los pronombres átonos, Madrid, Taurus, 1993, páginas $63-96$.

- El leísmo de las zonas no-leístas no ha sido aún bien estudiado. Los contextos sintácticos en que se produce son escasos y en muchos de ellos se ha hablado equivocadamente de leismo, por no haber comprendido que en ellos la variación pronominal entre le/lo, la no es libre, sino obligada por el significado de la construcción sintáctica. Hay que contemplar también la posibilidad, por ahora no valorada, de que existan en el área no-leísta diferencias geográficas en el empleo de esas construcciones. En las zonas noleístas hay, además, leísmo asociado al tratamiento de respeto con usted y, entre los hablantes cultos y los escritores, leismo aplicado exclusivamente a los referentes masculinos y personales por el deseo de aproximarse al uso más prestigioso de la lengua estándar peninsular. Véase para todo ello Fernández-Ordóñez, "Leísmo, laísmo y loismo", págs. 70-73 y 78-79. Puede encontrarse información (muy desigual) sobre este leísıno en: Juanita Carfora, "Lo and le in American Spanish". Hispania, LI, 1968, págs. 300-302; Gustavo Cantero Sandoval, "Casos de leísmo en México", Anuario de Letras, 1979, 
zonas donde el español convive con lenguas no-indoeuropeas carentes de la categoria de género ${ }^{10}$, y los lugares en que el leismo se acompaña de las otras dos confusiones pronominales, el laismo y el loismo.

XVII, págs. 305-308: Teudiselo Chacón Berruga, El habla de la Roda de la Mancha (contribución al estudio del habla manchega), Albacete, CSIC, 1981; Lidia Contreras, "Usos pronominales no-canónicos en el español de Chile", Estudios filológicos y lingüisticos. Homenaje a Angel Rosenblat en sus 70 años, Caracas, Instituto Pedagógico, 1974. págs. 157-176; Francesco D'Introno, "Alternancia lo/le en el español de Venezuela: análisis transformacional", Actas del primer simposio de corrientes actuales en la dialcctología del Caribe hispánico, editadas por H. López Morales, Editorial Universitaria de Puerto Rico, 1978, págs. 53-76; Erica C. Garcia, The Role of Theory in Linguistic Analysis. The Spanish Pronoun System, Amsterdam, North-Holland Linguistic Series, 19, 1975, y en colaboración con Ricardo Otheguy, "Dialect variation in leismo: a semantic approach", en R. Fasold, R. Shuy (eds.), Studies in language variation, Georgetown University Press, 1977, págs. 65-87; José María García Martín, "Nota sobre el leísmo en dos autores andaluces del siglo $\mathrm{xIx}$ ". . Anuario de Lingüística Hispánica, III, 1987, págs. 99-122; Charles E. Kany, Sintaxis hispanoamericana [1945], Madrid, Gredos, 1970, págs. 133-134, 137-139; Antonio Lorenzo Ramos, "Algunos datos sobre el leísmo en el español de Canarias". en M. Alvar (coord.), I Simposio Internacional de Lengua Española [1978]. Las Palmas, Ediciones del Excmo. Cabildo Insular de Gran Canaria, 1981. págs. 175-180, y "Observaciones sobre el uso de los pronombres en el español de Canarias", en M. Alvar (coord.), II Simposio Internacional de Lengua Española [1981], Las Palmas, Ediciones del Excmo. Cabildo Insular de Gran Canaria, 1984, págs. 253-263; Francisco Marcos Marín, Estudios sobre el pronombre, op. cit., págs. 229-238; Félix Monge, "Notas a una hipótesis sobre el leísmo", en Serta Philologica F. Lásaro Carreter, I, Madrid, Cátedra, 1983, págs. 441-453, y “A propósito de lc y lo", en G. Lüdi, H. Stricker, J. Wüest (eds.), Romania ingeniosa. Festschrift für Prof. Dr. Gerold Hilty, Bern-Frankfurt-New York-Paris, Peter Lang, 1987, págs. 347-363; Hans-Dietrich Paufler, "Quelques observations sur l'emploi des pronoms personnels dans la variante cubaine de la langue espagnole". Actele celui de-al XII-lea Congres International de Lingvistica si Filologie romanica, II, Bucarest, 1971, págs. 1-6; Mercedes Roldán, "The great spanish le-lo controversy", Linguistics, 147, 1975, págs. 15-30; Lenard Studerus, "Impersonal se $+l o(s), \operatorname{la}(s)$ : a tentative regional profile". Southwest Journal of Linguistics (El Paso, Texas), 7, 1984, págs. 57-68.

10 Tanto en contacto con el quechua (Ecuador, Perú, provincia argentina de Santiago del Estero) como con el guaraní (Paraguay, provincias argentinas de Corrientes y Misiones y oriente de las de Chaco y Formosa), el espafiol hablado por bilingües (y por monolingües poco cultos e incluso cultos) ofrece leísmo de persona y de cosa, masculina y femenina. La aparición de este leísmo americano con características semejantes en áreas tan diversas podria explicarse por la potente supervivencia en todas ellas de lenguas indígenas en contacto y por el hecho común de que todas esas lenguas carecen de la categoría de género. Ante la dificultad de establecer correctamente la referencia pronominal por un escaso dominio del género, el hablante inseguro del español opta por extender al acusativo el empleo de le, única forma sin género del paradigma. Este leismo puede acompañarse en las zonas hispano-quechuas del extraño uso de lo como único pronombre para toda referencia dativa o acusativa, masculina o femenina, singular y plural, empleo que parece corresponder al primer estadio del aprendizaje del español por los indígenas. Véase Fernández-Ordóñez, "Leismo, laísmo y loismo", art. cit., págs. 87-91. Aunque no todos los autores atribuyan este leísmo (y este particular loismo) al contacto secular del español con otras lenguas, dan noticia de estos fenómenos americanos M. A. Campos, El uso de los pronombres de objeto en el español de Moyobamba, Lima, Pontificia Universidad Católica del Perú, 1991, tesis inédita; Rocío Caravedo, "Espacio geográfico y modalidades lingüísticas en el español del Perú", en C. Hernández Alonso (coord.), Historia 
3. En el caso del empleo conjunto del leismo, el laismo y el loismo, es mérito de Flora Klein-Andreu haber probado la inadecuación de la hipótesis tradicional para explicar la aparición combinada de esos usos y haber propuesto una teoría alternativa a partir de datos recogidos de la lengua hablada $\mathrm{y}$ analizados desde la perspectiva sociolingüistica ${ }^{11}$. Basándose en un primer

y presente del español de América, Valladolid, Junta de Castilla y Lein y PABECAL, 1992, págs. 719-741; Rodolfo Cerrón-Palomino, "La forja del castellano andino o el penoso camino de la ladinización", en Historia y presente del español de América, páginas 201-234; Nélida E. Donni de Mirande, "El español en Santa Fe (Argentina). Cuestiones de historia lingǘistica y variación sincrónica", Anuario de Lingüistica Hispánica, VIII, 1991, págs. 131-149; Erica C. Garcia y Ricardo L. Otheguy, "Being polite in Ecuador. Strategy reversal under language contact", Lingua, 61, 1983, págs. 103-132; Erica C. Garcia, "Bilingüismo e interferencia sintáctica", Lexis, XIV, 1990, págs. 151-195; J. C. Godenzzi, "Pronombres de objeto directo o indirecto del castellano en Puno", l.e$x$ is, X. 1986, págs. 187-201; Germán de Granda, "Origen y formación del leismo en el español de Paraguay. Ensayo de un método", RFE, LXII, 1982, págs. 259-283; Kany, Sintaxis hispanoamericana, op. cit., págs. 134-135, 139, 148; Anthony G. Lozano, "Syntactic borrowing in Spanish from Quechua: the noun phrase", en R. Avalos de Matos, R. Ravines (eds.), Lingüistica e indigenismo modcrno en América. Trabajos presentados al XXXIX Congreso Internacional de Americanistas, Lima, Instituto de Estudios Peruanos, 1975, págs. 297-305; Inés Pozzi-Escot, "Norma culta y normas regionales del castellano en relación con la enseñanza", en Lingüistica e indigenismo moderno en América, págs. 321-330; Antonio Quilis, "Resultados de algunas encuestas lingüisticas recientes en el Ecuador", en Hommagc a Bernard Potticr, II, Paris, Klincksieck, 1988, págs. 649-658, y "Rasgos generales sobre la lengua española en el Ecuador", en Historia y presente del español de América, págs. 593-606; José Luis Rivarola, "Aproximación histórica al español del Perú", en Historia y presente del español de América, págs. 997717; Cristina A. Sanicky, "Las variaciones en el uso del pronombre en Misiones", Hispanic Linguistics, 3, 1989, págs. 185-197; Humberto Toscano Mateus, El español en cl Ecuador, Madrid, CSIC, 1953, Anejo LXI de la RFE; Beatriz Usher de Herreros, Castellano paraguayo. Notas para una gramática contrastiva castellano-guarani". Suplemento antropológico. Universidad Católica (Asunción), 11 (1-2), 1976, págs. 29-123; Berta Elena Vidal de Battini, "Zonas de leísmo en el español de la Argentina”, en A. J. Van Windekens, Communications et rapports du Premier Congrès International de Dialectologie générale, II, Louvain, Centre International de Dialectologie générale, 1964. págs. 160-163.

11 Véanse "Factores sociales en algunas diferencias lingüísticas en Castilla la Vieja", Papcrs. Revista de Sociología, 11, 1979, págs. 45-64; "Pragmatic and sociolinguistic bias in semantic change", en E. C. Traugott et al. (eds.), Papers from the Fourth International Conference on Historical Linguistics, Amsterdam, Benjamins, 1980, págs. 61-74; "Distintos sistemas de empleo de le, la, lo. Perspectiva sincrónica, diacrónica y sociolingüística", Thesaurus, XXXVI, 1981, págs. 284-304; "Neuterality, or the semantics of gender in a dialect of Castilla", en W. Cressey y D. J. Napoli (eds.), Linguistic symposium on Romance Languages: IX, Washington, D. C., Georgetown University Press, 1981, págs. 164-176; "Correction Strategies in Bi-dialectal Diglossia: from Caseless to Case-Distinguishing Usage in Spanish", comunicación inédita a New Ways of Analyzing Variation, etc., X, 1981; “Understanding Standards", en G. Davis y G. K. Iverson (eds.). Explanation in Historical Linguistics, Amsterdam, Benjamins, 1992, págs. 169-178; "What standard?", en R Fasold, P. Lowenberg and D. Schiffrin (eds.), Language variation and change. Cross-language perspectives, Amsterdam, Benjamins, en prensa. Debo agradecer a la profesora Klein-Andreu sus inteligentes observaciones sobre el contenido 
momento en el consabido parámetro animado/inanimado, Klein ubservó que los datos obtenidos de la lengua hablada vallisoletana desmentian las observaciones tradicionales sobre el leismo. Con referente masculino estaba más extendido en el singular con referentes animados que con inanimados, según era de esperar, pero en el plural, contra lo previsto, obtenia una difusión más amplia que la máxima alcanzada en el singular y, además, con indiferencia del carácter animado o no de los referentes. A ello sumó la constatación del laismo generalizado y la observación de que en el singular lo era el pronombre elegido cuando el referente era categorizado como continuo (con independencia de su género masculino o femenino y de si su posición sintáctica debía recibir caso acusativo o dativo). Como resultado, propuso un análisis nuevo de los parámetros que gobernarían estos usos ${ }^{12}$.

De acuerdo con la nueva interpretación, el uso de los pronombres átonos típicamente castellano, investigado en Valladolid, depende tanto del género que la lengua asigna al referente, como de su categorización sintáctica en discontinuo/continuo ${ }^{13}$. Es caracteristico del sistema castellano que se anule la concordancia de género si el objeto referido se categoriza como continuo; si, por el contrario, se categoriza como discontinuo, se conservan las marcas morfológicas de masculino y femenino. Hay que puntualizar que la posición sintáctica del argumento referido no es pertinente en el establecimiento de la referencia. Esto es, el leísmo, que sólo aparece cuando el referente masculino es discontinuo, se acompaña de laísmo y de loismo referido a entes continuos. Las frases siguientes ejemplifican estos usos, según Klein-Andreu ${ }^{14}$ :

le: le conoci en la mili; le dieron un cargo oficial.

la : la conocí en una fiesta; su novio la dio una sortija.

lo: lo tomamos en las comidas (la leche, el vino); hoy día lo añaden de todo (a la leche, al vino).

La distinción entre continuos y discontinuos no se extiende obviamente al plural, ya que sólo las entidades contables pueden pluralizarse, mientras que la confusión entre acusativo y dativo, en cambio, es en plural tan general como en el singular. La mayor regularidad del leísmo en plural se explica por la diversidad de los entes referidos en cada caso. Mientras que en el plural

\footnotetext{
de este artículo, asi como el haber puesto amablemente a mi disposición sus trabajos e investigaciones en curso sobre el sistema referencial castellano.

12 Para el leismo castellano, la idea ya había sido sugerida por Jesús Neira y por Francisco García González, véase infra, nota 54.

13 Para los conceptos de continuo y discontinuo, véase Ignacio Bosque, "Clases de nombres comunes", en Serta Philologica F. Lázaro Carreter, I, Madrid, Cátedra, 1983, págs. 75-88.

14 "Distintos sistemas", art. cit., pág. 300.
} 
todos los referentes son discontinuos, en el singular los referentes se dividen en discontinuos (referidos por $l e$ ) y continuos (referidos por $l o)^{15}$. Igualmente, el que sea el rasgo $+/$ - continuo lo que importa para establecer la referencia también explicaría que el leismo de "cosa" haya sido siempre menos frecuente que el "personal". Las personas y animales son esencialmente entidades contables, pero las "cosas" se dividen entre las contables (referidas por le) y las no-contables (por $l o)^{10}$.

Este sistema de uso de los pronombres recibe el nombre de referencial. Sistema porque se entiende que la elección de $l e$, la y $l o$ resulta en él tan obligatoria en la cadena sintáctica como lo es en el sistema "etimológico". Referencial porque los parámetros que deciden la elección del pronombre desatienden las distinciones funcionales de caso para atender exclusivamente al género y a la categorización sintáctica del referente en continuo o discontinuo.

La importancia del análisis de Klein-Andreu no sólo radica en los nuevos principios con que quiere explicar la variación en el uso pronominal, sino también en la observación sociolingüística de la misma. Ello le permite probar que existe, entre el sistema "etimológico" y el referencial, uno de compromiso, que caracteriza a la lengua culta peninsular. Ese sistema es básicamente "casual", con la salvedad de tolerar le para objetos directos animados o personales en el masculino singular. Coincide, pues, con lo prescrito por la Real Academia sobre el uso pronominal y con lo descrito por los gramáticos, y es el seguido mayoritariamente por los medios de comunicación así como por muchos de los hispano-hablantes cultos de regiones no-referenciales. Dentro de Castilla, según aumenta el nivel socio-cultural de los hablantes, el habla se aproxima proporcionalmente a ese sistema de compromiso. En zona referencial, como Valladolid, esa tendencia se manifiesta disminuyendo el laísmo y el leísmo para inanimados; en zona "etimológica", como Soria y Logroño, aumentando el leísmo en singular con referentes personales masculinos ${ }^{17}$.

En opinión de esta autora, que matiza una vieja idea de Cuervo ${ }^{18}$, el sistema de compromiso fue creado por algunos gramáticos ajenos a las confusiones que, al intentar comprender su funcionamiento desde fuera, reunieron

\footnotetext{
15 "Pragmatic and sociolinguistic bias", art. cit., págs. 68-70, y “Distintos sistemas", art. cit., págs. 5-6.

16 "Distintos sistemas", pág. 7.

17 Véanse "Factores sociales", "Pragmatic and sociolinguistic bias", "Distintos sistemas" y "Correction Strategies", art. cit. Lo demostrado por Klein sobre la existencia del sistema de la lengua estándar y sus características es también válido para las otras dos situaciones básicas de uso pronominal que hemos distinguido. Tanto en las zonas no-leístas como en aquellas que el español entra en contacto con lenguas indígenas, según aumente el nivel sociocultural de los hablantes, el empleo pronominal se ajustará progresivamente a ese sistema de la lengua estándar. Véase infra, nuestra nota 20 y los artículos de E. García citados en la nota 10.

18 "Los casos", pág. 104.
} 
los rasgos comunes a los sistemas "etimológico" y referencial. Le es el pronombre de los masculinos contables en el referencial y el mayoritario para los animados en el "etimológico", mientras que $l v$ se asocia con inanimados en el referencial y con masculinos en el "etimológico"; de ahi que, vistos los usos en conjunto, se identifique a le como pronombre para los animados y a $l o$ para los inanimados ${ }^{19}$.

La condena del sistema referencial, que la Real Academia viene formulando desde finales del siglo xviri, y la importancia que ha tenido ese criterio en la formación de la norma culta del castellano actual habrían influido de forma decisiva en el uso de los escritores y de los hablantes cultos desde tiempo atrás, de forma que los datos recogidos de la documentación escrita a partir de entonces poco o nada valen, ya que suelen estar condicionados por la normativa académica ${ }^{20}$.

La propuesta teórica de Klein-Andreu representa, desde mi punto de vista, un paso importantísimo en la correcta interpretación del fenómeno y supera los desaciertos metodológicos de las interpretaciones anteriores. En primer lugar, porque en vez de partir del análisis de textos escritos, fundamenta su teoría sobre la observación de la lengua hablada. Ello le permite ponderar los datos desde el punto de vista sociolingüístico, distinguiendo claramente el uso de la lengua culta (oral o escrita) del de la lengua hablada popular o coloquialmente. En segundo lugar, porque parte de la comprensión sincrónica del fenómeno, de cuyos datos podemos estar seguros, en vez de enfocarlo exclusivamente con una óptica histórico-etimológica. En tercero, porque, al no mezclar datos de las diversas zonas hispano-hablantes, puede probar que, incluso dentro de Castilla la Vieja, el español hablado en unas zonas no obedece a los mismos principios que en otras. En cuarto, porque enfoca el problema de la selección del pronombre desde un punto de vista estructuralista, y no como el resultado de tendencias lingüísticas de alcance variable e indeterminado.

19 Véanse "Understanding Standards", art. cit., págs. 169-175, y "What Standard?".

20 “Understanding Standards", págs. 171-175, y "What Standard?". En mi opinión, corrobora su análisis el contraste existente entre los resultados de investigaciones sobre el uso de los pronombres en el habla culta y en el habla popular de Madrid. Véanse, respectivamente, Antonio Quilis, Margarita Cantarero, María José Albalá y Rafael Guerra, Los pronombres le, la, lo y sus plurales en la lengua española hablada en Madrid, Madrid, CSIC, 1985, y Francisco Moreno Fernández ct al., "Anotaciones sobre el leísmo, el laísmo y el loísmo en la provincia de Madrid", Epos, IV, 1988, págs. 101-122. La misma tendencia a aproximarse al sistema de compromiso se detecta en los hablantes cultos de zonas distinguidoras. Véase, como muestra, los trabajos citados en la nota 9: García Martín, "Nota sobre el leísmo"; Cantero, "Casos de leísmo", pág. 308; Carfora, "Le and 10 ", pág. 301; Kany, Sintaxis hispanoamericana, págs. 133-134, 137-139; Marcos, Estudios sobere el pronombre, págs. 232-238; etc. 
4. Pese al indudable avance que representa esta nueva visión de los hechos, no son pocos los interrogantes que deja por resolver. De entrada, falta por investigar el plural del sistema referencial, que según bien sugería kleinAndreu ${ }^{21}$, pudiera ofrecer teóricamente variantes que seleccionaran los en vez de les como pronombre masculino de plural. Por otro lado, no se explican ciertas confusiones pronominales, como el loismo con referentes contables y el leismo con referentes femeninos. Tampoco se aclaran algunas de las estadisticas tradicionalmente observadas: que el leismo sea menos frecuente en plural que en singular, o lo contrario, que el loismo parezca más común en el plural. Por último, la interpretación de Klein sobre la génesis del sistema de compromiso no explica todos los datos recogidos en textos antiguos, en los que aparece leismo, principalmente singular y asociado a animados, sin laismo ni loismo, mucho antes que existiese el deseo consciente de creación de una norma culta española ${ }^{22}$.

Tampoco se especifica el preciso ámbito geográfico del sistema referencial $^{23}$. Desconocemos asimismo si este sistema es único o coexisten dentro del dominio castellano variantes del mismo, y también ignoramos exactamente dónde y por qué se originó, ni qué factores contribuyeron a su difusión, incógnitas que difícilmente pueden resolverse mientras no sepamos con precisión qué extensión presenta actualmente ni se lleve a cabo una reevaluación histórica de los datos de la lengua escrita basada en el nuevo planteamiento de análisis, y no sólo en el antiguo de recuentos de le y lo para animados e inanimados.

Ante estas carencias, inicié una investigación dirigida a establecer la demarcación exacta de los usos referenciales dentro de la Península y a comprobar la existencia y el funcionamiento del sistema descrito por KleinAndreu ${ }^{24}$. Desde el año 1990 vengo trabajando en esa línea mediante la reali-

21 "Distintos sistemas", nota 10, y "Neuterality", pág. 176 y nota 2.

22 Véanse los datos de Lapesa sobre el Poema de Mio Cid y las obras de Berceo ("Sobre los orígenes", págs. 527-531), los de Echenique ("El sistema referencial", páginas 131-136 y 146-147), así como los de Keniston para un conjunto de escritores de los márgenes castellanos (The Syntax, pág. 64).

${ }^{23}$ Antonio Llorente Maldonado de Guevara ("Consideraciones sobre el español actual", Anuario de Letras, XVIII, 1980, págs. 5-61, esp. págs. 22-27) ofrece datos sobre la extensión de las distintas confusiones, sin relacionar las unas con las otras. Posteriormente, él mismo ha rebatido los datos sobre Zamora y Salamanca ("Las hablas vivas de Zamora y Salamanca en la actualidad", en M. Alvar (coord.), Lenguas peninsulares y proyección hispánica, Madrid, Instituto de Cooperación Iberoamericana, 1986, págs. 101131, esp. págs. 127-128). Cfr. sus datos con el mapa de Klein (“Factores sociales”, art. cit., pág. 53), realizado sobre los resultados arrojados por un cuestionario que contestaron unos 200 hablantes procedentes de toda la Peninsula. Los datos aportados en las monografías dialectales se limitan a las localidades determinadas que son objeto de su estudio y, además, con cierta frecuencia no dan cuenta del comportamiento sintáctico de los clíticos.

24 Esta investigación, titulada "Diferencias geográficas en el uso de los pronombres 
zación de encuestas lingüisticas en la mitad noroccidental de España. Hasta ahora se ha encuestado en enclaves varios de las provincias de Asturias, León, Zamora, Salamanca, Cáceres, Badajoz, Ciudad Real, Toledo, Valladolid, Ávila, Palencia, Cantabria, Burgos, Madrid, Cuenca, Guadalajara, Soria, La Rioja, Álava y Vizcaya. Desde el punto de vista metodológico, los datos fueron obtenidos de grabaciones de la lengua hablada por los habitantes de zona rural y del estrato sociocultural más bajo, a los que se les supone la fijación de su ideal lingüistico en la conservación del sistema propio del lugar ${ }^{25}$. Gracias a los datos recogidos y a los que se pueden espigar de distintas monografias dialectales y sintácticas, estoy en situación de reconstruir en rasgos generales y de forma preliminar la distribución geográfica de los usos refe-

átonos en el español peninsular", ha sido financiada por la Universidad Autónoma de Madrid, dentro de las ayudas a grupos precompetitivos, en los años 1991-1993. En ese marco, tuvieron lugar tres campañas sucesivas de encuesta en los meses de julio de 1991, 1992 y 1993, en las que participaron un conjunto de estudiantes y licenciados en Filología Española de esa misma universidad: Teresa López Alameda, Dorotea Dominguez Martín, José Luis Forneiro Pérez, María José Gómez Pastor, Miguel Ângel López García (1991), Reyes Fernández Sánchez, María José González Arévalo (1991 y 1992), Teodora Fernández Olmo, Alicia Martín Leonor (1992), Rocio Barriopedro Macéin, Raquel Ezquerra Martínez, Ana Herrero Riopérez, Dolores Montero Reguera, Pilar Pecharromán García de las Hijas, Elena Varela Merino (1993), Belinda García Barba, José Ignacio Sanjuán Astigarraga y Roberto Sendino Gallego (1991, 1992 y 1993). Entre ellos, debo destacar a José Ignacio Sanjuán y María José González, que continúan colaborando conmigo en la transcripción de los materiales recolectados. Además, he contado con la colaboración de cuatro generaciones sucesivas de estudiantes de la asignatura de "Dialectología hispánica" (cuarto curso), que, dirigidos por mí, han realizado encuestas dialectales y elaborado trabajos sobre este aspecto de la sintaxis del español. Esas encuestas, realizadas en el marco del curso académico y de la asignatura de "Dialectología", han recibido el apoyo económico de la Facultad de Filosofía y Letras y del Departamento de Filología Española. No puedo dejar aqui de mencionar a todos los estudiantes: Mercedes García, Victoria Jordán, Teresa Lúpez, María José Luengo, Josefa Martín. Olga Espinosa, Carmen Hernández, Dulce María Toledo, Rosa María Luque, Armando Silles, Emilia Caballero, Pilar Fernández, Yolanda Guixé, José A. Saborit, Elena Torres, Reyes Yuste, José M. García, Elena Pardo, Elena Petierra, Alberto C. Fernández, Loreto Verdú, Sonia Vázquez, Ana Casado, Elena Garayzábal, Miguel Ángel Hernández, Rosario Rabazo (curso 1989-90), José Ignacio Sanjuán, Miguel Ángel López, Esther Aragón, Mercedes Gómez, María José Gómez, Miguel Angel Alonso, Teodora Domínguez (curso 1990-91), Fernando Pérez, Sara Ayuso, Paloma López, Roberto Sendino, Reyes Fernández, Teresa-María Rodríguez, César Alonso, Teodora Fernández, Adelina Villodres, Inmaculada Garcia, Belén Relaño, Amalia Riestra, Amelia Gonzalo, Encarnación Marín, Rufina Llanos, María José González (curso 1991-92), Rocio Barriopedro, Elena Benito, María Jesús Díaz, Patrocinio Gabaldón, Pilar Gómez de las Heras, Gregorio de Lucas, Alberto Morón, Antonio Navacerrada y Claret Ramos (curso 19921993).

25 Por lo general, nos hemos limitado a realizar una única encuesta en cada lugar, asumiendo los riesgos que entraña ese método si la selección del informante no ha sido óptima. Las entrevistas fueron diseñadas siguiendo módulos temáticos que facilitaran la aparición, durante la conversación, de pronombres átonos referidos a todas las clases posibles de argumentos (masculinos, femeninos, continuos, discontinuos, animados, inanimados, singulares, plurales) en posiciones sintácticas de dativo y acusativo. 
renciales y certificar que éstos no constituyen un sistema unitario, sino que, por el contrario, existen varios sistemas pronominales (de carácter total o parcialmente referencial) cuya demarcación interna no está por ahora bien delimitada. El modo en que esos sistemas se reparten sobre la península nos permite acometer un intento de explicación histórica sobre la génesis y la difusión del fenómeno.

\section{El Sistema REFERENCIAL.}

La matización más importante que resulta del análisis de nuestros datos respecto al sistema referencial descrito por Kiein-Andreu es el descubrimiento de que ese sistema no se presenta solamente bajo la forma esperada, sino que, por el contrario, coexisten variantes del mismo. La variación entre los distintos sistemas referenciales no radica en los parámetros lingüísticos que organizan la referencia pronominal, sino en la forma elegida para el plural masculino. Mientras que en el acusativo y en el dativo plurales femeninos parece utilizarse las invariablemente en todos los sistemas referenciales, en el plural masculino las soluciones adoptadas varían según se generalice una de las formas posibles, los o les, a costa de la otra, o bien se repartan los usos entre ambas en una proporción no siempre igualitaria.

1. Aunque la demarcación interna de estos sistemas no está por el momento bien trazada (dado que nuestras encuestas no han cubierto la totalidad de los territorios referenciales), pueden vislumbrarse tres áreas. Al norte, el sistema referencial que se extiende hacia el sur a ambas orillas del río Pisuerga (desde su nacimiento hasta que desemboca en el Duero), esto es, Palencia, Valladolid, y el occidente de Burgos, sistema que prefiere les como forma de plural masculino [sistema (a)]. El segundo tipo de sistema referencial que conozco se encuentra al sur, al menos, en el occidente de Toledo, la mitad oriental de Cáceres, la esquina nororiental de Badajoz, en la Salamanca fronteriza con Ávila, en el sur de esta última provincia y en el occidente de Madrid. En él los es la única forma empleada en el plural masculino [sistema (b)]. Entre ambos sistemas, septentrional y meridional, se extiende una zona de limites imprecisos en que parecen alternar en el uso los y les [sistema (c)]. Aunque sin duda su extensión debe ser mayor, puedo documentar este sistema en la mayor parte de Burgos (salvo en el occidente y en la zona al norte del Ebro), así como en el oeste de Soria. 
Sistema (a) ${ }^{26}$ :

\begin{tabular}{|c|c|c|c|c|c|}
\hline \multirow{4}{*}{ ACUSATIVO } & \multicolumn{3}{|c|}{ SINGULAR } & \multicolumn{2}{|c|}{ PLURAL } \\
\hline & \multicolumn{2}{|c|}{ CONTABL.E. } & \multirow[t]{2}{*}{ NO-CUNTABLE } & MASCTLINO & FFMENINO \\
\hline & masculino & femenino & & & \\
\hline & le & la & lo & les & las \\
\hline DATIVo & le & la & lo $\sim$ le & les & las \\
\hline
\end{tabular}

Ejemplos de (a) ${ }^{27}$ :

Acusativo singular:

le: le matábamos, pues normal, en casa, siempre hay un señor que sabe sangrar ... y él nos le mataba (el cerdo); si pesa catorce quilos, hay que tenerle veintiocho dias, el doble, después ya se le saca... aproximadamente siete o ocho meses le tenemos colgao (el jamón); este salón le hicieron en el año 45 ¿verdad?, y le abrieron en el 46; por no comprar el anillo ni nada, cogían y se le pedian a la vecina o a la familia de la otra; no es de aquí el chico ... ahora le han trasladado a Palencia.

la: siempre al portal, y cuando ya eras novio, porque a lo mejor la ibas a acompañar y la acompañabas hasta casa; nosotros la pusimos la calefacción porque ... la prendemos cuando nos parezca; me faltaba una hogaza, pos entonces se la pedia a la vecina, y mañana ya, cuando cocía yo, se la devolvía.

lo: la sangre hay que revolverlo para que no se cuaje; viene a recoger la leche y lo lleva a Quintana, todas las mañanas viene una cisterna que compra leche de vacas y de ovejas también para llevarlo ahí a Baltanas... hay mucha gente que compran, yo, porque lo gasto de paquete, la verdad, por no ir a comprarlo, pero hay mucha gente que compra leche a los que tienen vacas; después emparvábamos en la era, haciamos una parva grande de paja y grano, lo amontonabas con la horca, y después ya esa paja lo llevábamos a

26 Puedo reconstruir este sistema sobre mis propios datos y los parciales proporcionados por algunos autores. Obedece a este sistema el habla rural de Villabáñez, junto a Valladolid, analizada por Klein-Andreu en sus trabajos. Sobre Burgos capital disponemos de la información de F. Miguel Martínez Martín ("Datos sobre el leísmo y el laísmo de persona en el habla de la ciudad de Burgos", Epos, I, 1984, págs. 159-176), que confirma la generalización del leísmo y laísmo personales tanto en singular como en plural. Llorente ("Las hablas vivas", art. cit., pág. 127) dice que existe leísmo +/- animado y laismo en dos pueblos de Salamanca y Zamora fronterizos con Valladolid (Tarazona de la Guareña y Vadillo de la Guareña). Según nuestras encuestas, parece utilizarse este sistema (en singular y plural) en Tordómar, Cobos de Cerrato, Villafruela, Barruelo de Villadiego, Montorio, Castellanos de Castro y Aranda de Duero (Burgos).

27 Estos ejemplos fueron recogidos en Cobos de Cerrato (Palencia) y en Tordómar (Burgos) y debo su transcripción a María José González Arévalo. 
los pajares pal ganao y el grano teníamos que coger a acribarlo, que decíamos, con un caldero lo echábamos otra vez a la máquina por dejarlo limpio.

Dativo singular:

le: luego le limpian y le sacan todas las tripas y las asaduras (al cerdo); antes le he dicho que le daría veinte duros (al nieto).

la: cuando se casaba era costumbre de comprarla a la novia el traje; hay una cosa de cofradia que pagamos todas las mujeres para sacar a la Virgen cosas, para comprarla a la Virgen mantos; yo a la mayor la di año y medio pecho.

le $\sim 10$ : eso ... hay que ponerlo a cocer ... y estar dándole vueltas, dándolo vueltas hasta que creas; pan con vino y se le echaba azúcar; envuelven la manteca con la cebolla y le dan unas vueltas; lo eché, lo dí una vuelta, lo amasé bien bien la carne.

\section{Acusativo plural:}

les: aquí la gente ya no les cría en casa, les cría en criaderos de cerdo; los jamones tantos quilos como pesen, tantos días les tienes que tener metidos en ... hay que tenerles veintiocho dias metidos en salmuera que llaman; hay unas que les comen congelaos, les sacan cuando van a comerles, pero yo les meto en aceite y en una olla de accite csos aguantan, todavía les tengo desde que matamos en enero (los chorizos).

las: las morcillas, esas hay que comerlas muy pronto; sólo hay dos pastores que las tienen (ovejas); venga a rondar a las mozas y a tirarlas de las camas.

\section{Dativo plural:}

les: los padres, si ven que no les parece bien, pues a lo mejor decían...; los pastores, ... en vez de darle trigo, les dabas centeno a lo mejor; a esos 18 huevos se le quitan nueve claras, a esos 18 huevos se les echa medio quilo de manteca y medio de azúcar. las: se limpiaban con una hoz, irlas cortando el cuello con una hoz (a las remolachas); y después, cuando están fritas las magras que llamamos nosotros, meterlas en unas ollas y taparlas con el aceite que las he frito.

A veces, el sistema (a) parece tender a eliminar la distinción entre contables y no-contables, pretendiendo suprimir lo como pronombre reservado para la referencia a los entes continuos. Para comprender esta reducción, hay que tener en cuenta que el rasgo más marcado por su carácter dialectal en todos los sistemas referenciales es el empleo de lo para no-contables femeninos, y es, en consecuencia, el primero que pierden ${ }^{28}$. De ahí que, generalizado $l a$ para el femenino, surge la tendencia a convertir a $l e$ en la única forma para el masculino. Ello se fomenta también en que lo no logra desplazar totalmente a le del área del dativo referido a continuos. Llamaré ( $\left.a^{\prime}\right)$ a este sistema en que

28 Véase lo que dice al respecto Francisco García González en "El leísmo en Santander", Estudios ofrecidos a E. Alarcos Llorach, III, Universidad de Oviedo, 1978, págs. 87-101, e infra, pág. 93 y nota 44 . 
tiende a desaparecer $l o$ para no-contables (aunque se mantiene obviamente para el neutro) ${ }^{29}$ :

Sistema (a'):

\begin{tabular}{|c|c|c|c|c|c|c|}
\hline \multirow{4}{*}{ ACUSATIVO } & \multicolumn{4}{|c|}{ SINGULAR } & \multicolumn{2}{|c|}{ PLURAL } \\
\hline & \multicolumn{2}{|c|}{ CONTABLE } & \multicolumn{2}{|c|}{ NO-CONTABLE } & MASCULINO & FEMENINO \\
\hline & masculino & femenino & masculino & femenino & & \\
\hline & le & la & le & la & les & las \\
\hline DATIVO & le & la & le & la & les & las \\
\hline
\end{tabular}

Ejemplos de $\left(a^{\prime}\right)^{30}$ :

Acusativo singular:

le: [ $e$ dónde guardaban la paja?] en un local como esto, por ejemplo, y hasta que le llenabas; [ $¿$ habia horno en todas las casas?] todavia le tengo yo; pues le descosen el colchón, le vuelven a hacer otra vez, y queda hueco; se llevaba el santo ... y luego le traían otra vez; estrazarle, desurdirle, partirle en trozos (el cerdo); [¿ bebian mucho vino aqui ?] yo le conoci a mi padre y le oi decir que un año le tiraron, venía la cosecha buena y le tiraron; ¿con el grano? pues eso, venderle, pal ganao y venderle, el que sobraba venderle, y el trigo le vendía; el campo no da nunca nada, luego le tienen despreciao los gobiernos; café, aqui es café, pero que no le hay, no le venden por ahí.

$l a$ : ibamos por agua, la traiamos al cadril; [ $y$ y con la cebada qué hacen?] pues pa ganaos, y venderla, si vienen a comprarla; pues hay una chica que la abre, pa verla (la iglesia); los antepasados también la bajaron porque llovió (la virgen); y los padres iban a pedirla, pues llegaban los padres y iban a pedir la novia.

Dativo singular:

$l e$ : a éste no le gustan; bastante le dábamos, le dábamos todo el cuerpo (al novio); se limpiaba y luego le das otra vuelta (al trigo); el salchichón le echamos ingredientes diferentes.

29 Este es el sistema que describe Santiago de los Mozos (La norma castellana del español, Valladolid, Ámbito ediciones, 1984, págs. 15-35) como característico de Castilla. Aunque $l o$ todavía compite con fuerza con le (y débilmente con $l a$ ) en la referencia a los entes continuos, parecen obedecer a este sistema los datos que hemos acopiado en Tierra de Campos: Valderas (León), Prado y Cotanes (Zamora, junto a la frontera con Valladolid), San Cebrián de Mazote, Pozuelo de la Orden y Cabreros del Monte (Valladolid).

30 Los ejemplos de (a') aquí ofrecidos proceden de San Cebrián de Mazote (Valladolid) y Prado (Zamora) y debo su transcripción a José Ignacio Sanjuán Astigarraga. 
la: a mi nuera la gustan mucho; el novio la regalaba el traje (a la novia); echan la leche, la echan cuajo; la lana de las ovejas la lavaban, la daban unos palos bien, y luego al colchón ${ }^{31}$.

\section{Acusativo plural:}

les: ¿ para vivir? pues unos taburetes que ahora se les enseñaré yo los que teníamos; hubo que quitarles porque no se podia arar (los majuelos); tienen que ser chorizos muy buenos, y si no eso, ya no les queremos; pues les cebaban y luego les mataban y les comían (a los cerdos); el que necesitaba, les buscaba (segadores).

las: se cortaban las cabezas de los gallos y luego las cenaban, los matrimonios; yo las conoci con faldas largas (a las mujeres).

\section{Dativo plural:}

les: a ver dónde iban, o cómo hacian, o qué les daban (a los novios); les daban de comer y cuando acababan, les daban eso, la soldadilla, y ya marchaban (a los segadores); venían cada ocho días o cuando les parecía (los guardias).

las: como ahora, que las ponen la gota (a las mujeres de parto); las digo yo, venid acá (a las niñas); trabajaban pa otros, las daban el jornal y iban ... llevaban faldas casi hasta el suelo, aunque se agachaban, no las viera nadie nada (a las mujeres).

Sistema (b) ${ }^{32}$ :

\begin{tabular}{|c|c|c|c|c|c|}
\hline \multirow{4}{*}{ acUsativo } & \multicolumn{3}{|c|}{ SINGULAR } & \multicolumn{2}{|c|}{ PLURAL } \\
\hline & \multicolumn{2}{|c|}{ CONTABLE } & \multirow[t]{2}{*}{ NO-CONTABLE } & \multirow[t]{2}{*}{ MASCULINO } & \multirow[t]{2}{*}{ FEMENINO } \\
\hline & masculino & femenino & & & \\
\hline & le & la & lo & los & las \\
\hline DATIVO & le & la & le $\sim$ lo & los & las \\
\hline
\end{tabular}

s1 La persistencia de lo en la referencia a entes continuos se percibe tanto en el acusativo como en el dativo, según muestran estos ejemplos: "luego se saca la carne y eso se pica, con una máquina lo pican, lo echan el pimiento y la sal, lo tienen dos días". Pero el lo se reserva ya con preferencia para la indeterminación, rasgo propio de lo neutro. Compárese el $l a$ dativo referido a leche frente al $l o$ dativo referido a la mezcla de la leche con el cuajo: "echan la leche, la echan cuajo, que era cuajo, no como ahora, el estómago del cordero, lo daban unas vueltas y cuajaba, ... y al día después lo echaban sal".

32 A diferencia de los sistemas (a) y (a'), el sistema (b) era hasta ahora completamente desconocido (si bien Klein-Andreu había previsto su viabilidad teórica, "Distintos sistemas", nota 10, y "Neuterality", pág. 176 y nota 2). He documentado su existencia en los montes de Toledo, así como en la parte occidental de esa provincia (Arisgotas, Cerralbos, Caleruela, Los Navalucillos, Villarejo de Montalbán, La Pueblanueva, La 
Ejemplos de (b) ${ }^{23}$ :

Acusativo singular:

le: hacer un poder notarial pa mandársele; no le mató (a un buho); el jamón le colgamos pa que se ponga tieso; enchúfale (el brasero).

la: tenian que matar alguna cabra pa comérsela; me echaban una perra al suelo y no la cogía; estaba pa dar a luz y fue a cuidarla (a la cuñada).

10: no lo podemos comprar fresco (el pescado); ¿he perdido el hilo? ¿no lo tengo por aqui ?; haciamos el pan, lo llevábamos al horno, lo cocíamos, lo masábamos nosotros; venden la leche, aqui, yo tengo ganas ya de que lo quiten pa traerlo de botellas embotellao; ; claro! el que tiene madera, pues lo vende, se lo vende a un maderero; tengo la leña de hacer la lumbre, allí, y lo meto yo; el nitrato se lo compra y aquí está.

\section{Dativo singular:}

le: ¡Que yo pueda echarle una mano! (a él); se le saca el vientre (al cerdo); no se le recorta el tocino (al jamón); le metes al jamón un poco de sal.

la: me han dado cincuenta mil pesetas pa que la pagara el gasto (a la hija); la ha gustao estudiar (a la novia de su hijo).

lo $\sim$ le: ese es un ganado seleccionado que tiene un señor ahí que le obtiene unos buenos dineros; se lo echa nitrato (al campo, a la siembra) ${ }^{\mathbf{4}}$.

Nava del Ricomalillo, Buenasbodas), en la zona oriental de Cáceres, al este de la línea que une Béjar con Plasencia (Navalvillar de Ibor, Castañar de Ibor, Villar de Plasencia, Jarilla, Garganta de la Olla), sur de Ávila (Mombeltrán), franja oriental de Salamanca (Santibáñez de Béjar, Alba de Tormes, Tordillos) y noroccidente de Madrid (Horcajo de la Sierra, Montejo de la Sierra, Lozoya, Bustarviejo, Navalafuente). Las impresiones de Llorente sobre Salamanca encajan con mis datos: "El leísmo de Complemento Directo masculino de persona, animal y cosa, más el leísmo y el loísmo, los encontramos en Cerecinos de Campos, en Aldeaseca de la Frontera, en Pedraza de Alba y en Santibáñez de Béjar" ("Las hablas vivas", art. cit., pág. 127), todos ellos fronterizos con Avila, salvo Cerecinos. Un sistema parecido es el que debe existir en Cespedosa de Tormes (en Salamanca junto al límite con Ávila) por lo que dice Pedro Sánchez Sevilla, pese a que no menciona el loísmo: "Siguiendo la corriente general castellana se ha introducido el uso de le por lo, acusativo etimológico, no sólo hablando de personas, sino también de animales y cosas que fácilmente pueden ser personificadas; ejemplos: "ique me llevo el niño, que me le llevo!"; "da pa'cáll burro, dale pá'ca"; "yo te cargo el saco, yo te le cargo". Sólo se reserva el lo para las cosas inertes, como "ahí va el barro, ¿dónde lo echo?"; "debo un poco de pan, a ver si lo peso y lo llevo". General es el uso de la por le, dativo femenino etimológico: "dala un cachete" ("El habla de Cespedosa de Tormes (en el limite entre Salamanca y Ávila)", RFE, XV, 1928, páginas 131-172 y 244-282, esp. págs. 244-245).

3s Los datos aquí ofrecidos fueron grabados en Navalvillar de Ibor y Castañar de Ibor (Cáceres), salvo los ejemplos de lo para referente femenino continuo, que proceden de Mombeltrán (Ávila). Debo su transcripción a Esther Aragón Pividal y a Miguel Anngel López García de la Cruz, respectivamente.

34 Estos ejemplos de lo para dativo en los no-contables deben relacionarse con el lo de dativo neutro que también aparece en la zona de vez en cuando: "i yo lo doy tanto valor a eso!" (Villar de Plasencia). 
Acusativo plural:

los: aqui no los hay (jóvenes); los obligaban a ir, venían y se los llevaban (los mozos a la mili); los cerdos criábamos pa comerlos nosotros; se juntan varios hombres y los agarran y los matan (los cerdos); no sabemos si los venderán ahí (los manteles); después de tenerlos altísimos los cerezos; ¿̇sabes con qué se los pela ahora? (a los cochinos); los chaquetones se los metía por las mangas (se metian).

las: las vacas nos las compraba otra gente rica; iban a buscar las mondas de las patatas, de las naranjas y los plátanos pa comérselas.

\section{Dativo plural:}

los: iban buscándote pa que los dieras la merienda (los niños); lo que los parecía, lo mataban (los maquis mataban a los animales); encendian el cigarro pa que los diera miedo (a los lobos); los voy sacando las costillas (a los cerdos); a mis perros yo los echo pan.

las: no me las han dado nunca nada (a las hijas); a las gallinas las echo cebada y pienso.

Este sistema es probablemente el que intentó describir Correas en la Salamanca de principios del siglo $\mathrm{XVII}^{35} \mathrm{y}$ debe estar muy extendido en toda la provincia de Ávila, según nos lo hacen suponer anotaciones diversas sobre el leismo, laísmo y loísmo (normalmente plural) de escritores nacidos en esa provincia $^{36}$. La explicitación de este sistema permite explicar algunas obser-

35 En su Trilingüe de tres artes de las tres lenguas Castellana, Latina i Griega (Salamanca, 1627) dice: "Para los últimos he dexado estos articulos pospositivos, rrelativos, encliticos, fixados i asidos, Le, les, los, La, las, Lo, porque ai mucho que dezir dellos, i que advertir el abuso que ai en usar algunos dellos confusamente [...]. Digo pues que Le es masculino, i tiene dos plurales, les para Dativo solamente, y los para Acusativo las más vezes, i algunas para Dativo; la, las es femenino: lo Neutro" (apud Cuervo, "Los casos", págs. 222-223). Salamanca, en el límite entre el sistema distinguidor y el confundidor, no generalizaba los para dativo. También veo atisbar un sistema semejante a (b) en algunos de los textos medievales estudiados por Echenique, en que el leismo en el singular con referente de persona masculina coincide con el de cosa, con el loísmo plural y con la ausencia de leismo en el plural ("El sistema referencial", art. cit., páginas 132-138, 142-145, 146-148, 150-152).

36 El análisis de Benezech ("Remarques sur les pronoms atones", art. cit.) de los textos de tres autores de zona castellana, Miguel Delibes (Valladolid), Ramón de la Cruz (Madrid) y José Jiménez Lozano (Avila) en lo que respecta al uso de los pronombres átonos permite observar, pese a tratarse de lengua escrita y haber sido analizada desde el parámetro $+/$ - personal, ciertas tendencias que manifiestan la separación del sistema (a), de Delibes, del sistema (b), de Jiménez Lozano. Este autor abulense es leísta en singular de persona y parcialmente de cosa, laísta absoluto en singular y plural, no es apenas leísta en plural (a diferencia de Delibes), mientras que es el único en ofrecer un ejemplo de loismo plural ("aunque a algunos los gustaba": pág. 39). Probablemente el sistema (b) era también el que latía tras el uso pronominal de Santa Teresa, leísta, laísta y loísta en plural (cf. Cuervo, "Los casos", págs. 101, 109, 111) y Keniston (The Syntax, pág. 70). 
vaciones que se venian haciendo tradicionalmente sobre el loismo: el hecho de que fuera menos frecuente en singular que en plural y que en los Siglos de Oro apareciera entre autores nacidos en las cercanias de Madrid ${ }^{37}$.

\section{Sistema (c) ${ }^{38}$ :}

\begin{tabular}{|c|c|c|c|c|c|}
\hline \multirow{4}{*}{ ACUSATIVO } & \multicolumn{3}{|c|}{ SINGULAR } & \multicolumn{2}{|c|}{ PLURAL } \\
\hline & \multicolumn{2}{|c|}{ CONTABLE } & \multirow[t]{2}{*}{ NO-CONTABLE } & \multirow[t]{2}{*}{ MASCULINO } & \multirow[t]{2}{*}{ FEMENINO } \\
\hline & masculino & femenino & & & \\
\hline & le & la & lo & los $\sim$ les & las \\
\hline DaTIVo & le & la & le $\sim$ lo & les $\sim$ los & las \\
\hline
\end{tabular}

Ejemplos de (c) ${ }^{39}$ :

Acusativo singular:

le : en Burgos no se puede tirar el cántaro porque no le llevan en la mano con agua, las mozas, ¿ tú sabes lo que es un cántaro con agua? En Burgos no le lleváis ni en Madrid, no le podéis tirar; fui con un traje que le tenía de antes, de los domingos, de las fiestas. de lo que sería; [ ¿ cómo se mataba al cerdo?] Pues cogerle, atarle, le echaban en una banca y le sangraban; le he tapao con una ropa por encima pa que no le picarian las moscas (al niño).

la: tenía que venir, si queria verla, siete o ocho kilómetros a pie (a su futura mujer); el que tenía dos pesetas, tenía que mirar, porque mañana ... salía una finca, a ver si la comprabas.

37 Desconozco la frontera oriental de este sistema (b), aunque no sería extraño que alcanzase no sólo el occidente, sino gran parte de la provincia de Madrid. Piénsese, por ejemplo, en el uso de Quevedo, madrileño, que también era leísta, laista y loísta (cf. Cuervo, "Los casos", págs. 102, 110, 112, y Marcos, Esiudios sobre el pronombre, págs. 195-206). Según Llorente ("Consideraciones", pág. 26), hay loísmo "en Madrid, Segovia, Valladolid, Avila (capitales y parte de las respectivas provincias), parte de las provincias de Toledo y Palencia y la orla oriental de Zamora y Salamanca", impresiones que coinciden parcialmente con nuestros datos.

38 Según nuestras encuestas, parecen obedecer a este sistema Villálvaro, La Hinojosa (Soria), Coruña del Conde, Mecerreyes, Puentedura, Covarrubias, Cerratón de Juarros, Villamóndar, Olmos de Atapuerca, Santa María del Mercadillo, Gumiel del Mercado, Temiño, Quintanabureba, Quintanaloranco, Villasur de los Herreros, Cabañas de Juarros, Barcina de los Montes, Salas de Bureba, Abajas, Castrillo de Solarana, Jaramillo de la Fuente, Vizcaínos, Montoto de Bezana, Covanera, Orbaneja del Castillo, Virtus, Población de Arreba (Burgos), Ruanales, Reinosa y Arroyal (Cantabria).

* Los ejemplos siguientes fueron recogidos en Cabafias de Juarros y Temiño (Burgos) y debo su transcripción a María José González Arévalo. 
1o: el arroz hay quien lo echa cocido, yo to echaba sin cocer, lo lavaba ...; hay pueblos que vienen a coger la leche, vienen lecheros de Burgos a recogerlo; si te hace falta hilo para coser, tienes que comprarlo; la leña hay que quitalo, harrelo bien [del horno]

Dativo singular:

le: le cogian así las patas y le atan a la banca, y le atan las patas luego con un cordel. y después le metían el cuchillo así (al cerdo); y le dije una vez al médico...; al poco tiempo ya le daba una patatilla bien deshecha como que era puré (al niño).

la : la cerda que criaba cerdos, pues se la echaba de comer; ipor Dios, no se la ocurra a usted, que sc la muere el niño!

$l o \sim l e$ : habia que dalo vueltas en un cubo, dalo vueltas pa que no se cuajaria (la sangre del cerdo); la harina, conforme está para hacer el pan, echabas la harina, lo ibas dando vueltas hasta que iba quedando ya más tieso la sangre... después se echaba ya la sal, un poco pimiento, pimienta, se echaba la sangre, se le daba vueltas (a la masa de la morcilla); y el que vende la leche sí lo llevara bueno, pero después ¿cuántas cosas le echarán?

\section{Acusativo plural:}

los les: eso una vez que quitamos la sal, que se los lava, se los adoba, despues se los cuelga, ya sc curan y a comeles (los jamones); los lomos se pueden freir, se pueden adobar y se les puede tomar con aceite; yo les tenía un año en casa ... y venderlos de pequeños o engordarles y venderles de gordos (a los cerdos); los vendíamos porque entonces andábamos todos mal de dinero y vendía los pollos pa sacar cuatro perras; aquí los corderos se quedaban pa matarlos; hombre, iclaro que habia que cuidarles! (a los bueyes).

las: aqui las que hacíamos las haciamos para mucho tiempo, no es como en la capital, que las hacen y las venden (las morcillas); aunque tenías mil pesetas, no las podías gastar.

Dativo plural:

les $\sim$ los: a los chorizos echalos en aceite y dalos vueltas; les daban aunque sea un par de huevos o tres, unos chorizos muy largos... les pasaba el alcalde media cántara de vino pa que beberían (a los quintos); [¿ cómo criaban los cerdos?] Pues echándolos en un..., que se los echaba alli de comer; como les ataban las patas, con tres o cuatro [hombres] que habria, ya valía (a los cerdos); con la yegua a llevarles el pan dos veces a la semana, y les cobraba a cinco pesetas el quilo (a los carboneros).

las: se hacían asi extendidas, las hacías unos cortes y las metías al horno cuando estaba el horno caliente, y allí se cocían, y con eso, pues las dabas vueltas pa que no se quemaran (a las hogazas); ahora es al revés, que las ponen de ropa $\mathbf{y}$ de cacharros y de todo, el piso lleno de todo (a las novias).

La frecuencia con que los y les alternan como formas del plural masculino no es la misma en lọs contextos de acusativo y en los de dativo ${ }^{40}$. Si con-

40 No obstante, en algunas localidades la proporción de ejemplos es igualitaria para los y les tanto en el acusativo como en el dativo. Eso sucede con nuestros datos de Milagros y Quintanaloranco (Burgos). 
sideramos conjuntamente los datos recogidos en toda el área en que conviven los y les en el plural, resulta interesante observar que esas dos formas parecen coexistir en una proporción igualitaria en el acusativo ${ }^{41}$, mientras que en el dativo les aparece como la forma única o la preferida mayoritariamente ${ }^{42}$. La extensión de les al acusativo podría estar condicionada por el carácter animado de los referentes y la de los al dativo, inversamente, favorecida por el inanimado.

2. La variación en las formas seleccionadas para el plural masculino y la extensión que parece presentar el sistema (c) en que alternan los y les muestran claramente la dificultad principal que se opuso en el sistema "etimológico" a la extensión del referencial. Mientras que todos los pronombres del antiguo paradigma encontraron un significado funcional concreto en el nuevo, para la expresión del plural masculino el sistema "etimológico" ofrecía dos formas. los y les, en vez de una. Por un lado, la analogía con otras series pronominales pudo favorecer la selección de los, apoyada por los plurales masculinos ellos, estos, esos, aquellos. Por otro, les parece resultar la más adecuada desde el punto de vista de la coherencia interna del sistema referencial. Mientras que $l o$ sirve para referir a entidades que no pueden pluralizarse, las continuas, le es el clítico empleado en el singular para referirse al mismo tipo de entidades a las que se remite necesariamente en el plural, las discontinuas. Si el plural de la es las, el de le debería ser les.

En cambio, no es extraña la clara preferencia por las para remitir a entes femeninos plurales. Puesto que en el sistema referencial el único rasgo pertinente para el establecimiento de la referencia en el plural es el género, las era la única forma disponible que podía señalarlo sin ambigüedad.

Aunque no es en absoluto evidente cuál de estas tres soluciones del plural sea la más antigua ${ }^{43}$, su existencia aclara algunas de las observaciones

11 Sin embargo, y sin que la distribución geográfica guarde alguna coherencia, hay lugares que en la encuesta prefirieron el acusativo los (Santa María del Mercadillo, La Hinojosa, Mecerreyes, Villasur de los Herreros, Temińo, Quintanabureba), y otros que favorecieron claramente a les (Coruña del Conde, Puentedura, Jaramillo de la Fuente, Vizcaínos).

12 Los sólo penetra en el dativo en un porcentaje máximo del $15 \%$.

43 No obstante, según se expone más adelante, la distribución geográfica de los usos referenciales combinada con la historia me conduce a suponer la mayor antigüedad del sistema (c), en que alternan los y les, a partir del cual se habrían producido dos reorganizaciones independientes del sistema: una, al norte, que favoreció la generalización de les, otra, al sur, que prefiró la forma los. Pero también es igualmente posible concebir que el sistema (a) fue el de creación más antigua y que en su extensión hacia el este y el sur experimentó una acomodación progresiva ante la utilización de la forma los como acusativo plural masculino en los sistemas "etimológicos" vecinos, adaptación que 
que se venían haciendo tradicionalmente. Si el leismo en el plural está estadísticamente menos extendido que en el singular, ello se explica por ser les el pronombre masculino del plural sólo en uno de los subsistemas referenciales. Reunidos los datos de individuos procedentes de varias zonas castellanas, es evidente que les nunca podía ganarle la batalla numérica a los. Por otra -parte, la frecuencia más alta del loísmo en plural se entiende si consideramos dos hechos. Primero, que sobre el total de ejemplos de uso pronominal los casos de dativo referido a entes continuos es siempre muy escaso. Segundo, que existe un subsistema referencial que ha hecho de los la forma del plural masculino y otro en que los alterna con les en ese contexto.

3. El empleo de $l o$ como dativo referido a continuos en alternancia con le en todas las áreas referenciales prueba la resistencia (o lo tardío) de la introducción del acusativo $l o$ en ese contexto sintáctico, frente a la aparentemente fácil y temprana extensión al dativo de otros pronombres acusativos, como la, las (e incluso los), quizá debida a su excelencia en señalar el género, virtud de la que carece $l o$.

En todos los subsistemas referenciales, por otro lado, el rasgo que se siente más "dialectal" es el empleo de lo como pronombre para la referencia a entes continuos femeninos. De ahí que, según aumenta la cultura del hablante, el empleo de $l o$ en ese caso tienda a desaparecer y se reemplace por $l a^{4}$. Ello también puede haber influido en la dificultosa expansión de $l o$ al dativo.

4. El desplazamiento del sistema "etimológico" por el sistema referencial en sus diversas variantes puede ( $\mathrm{y}$ debe de) estar condicionado por el tipo de contexto sintáctico ${ }^{45}$. Aunque el análisis pendiente de nuestros datos no

originaría los sistemas (c), primero, y (b), después. No veo cómo el sistema (b) pueda ser el más antiguo.

44 lo alterna con la para la referencia de los no-contables femeninos especialmente en el área más meridional del sistema referencial (zona b), como, por ejemplo, en Tordillos, Caleruela; incluso en algunos lugares $l a$ se ha convertido en la forma única del femenino, con independencia del rasgo $+/$ - contable. Así, por ejemplo, en Castañar de Ibor y Navalvillar de Ibor (Cáceres). Lógicamente, este 10 de origen astur-leonés se conserva en el ámbito de la referencia a los continuos femeninos con mayor vitalidad en el norte de Castilla. Francisco García González lo describe plenamente vigente en toda la provincia de Palencia (ejemplos de Salinas de Pisuerga, Becerril de Campos), la zona norte de Valladolid (única explorada; ejs. de Fuensaldaña, Wamba, Herrín de Campos, Villacid de Campos, Cigales, Pesquera de Duero), la mayor parte de la provincia de Burgos, con lo muy intenso en la zona norte y occidental (ejs. de Espinosa de los Monteros, Melgar, Oña, Salas de los Infantes) y franja este de la provincia de León, desde Oseja de Sajambre hasta Cistierna, desde donde la isoglosa se prolonga hacia el sur siguiendo el curso del río Cea (ejs. de Valmartino, Almanza, Saelices del Río) ["le (lu), la, lo (lu)/ en el Centro-Norte de la Península", Verba, 8, 1981, págs. 347. 353, esp. págs. $350-351]$.

15 En conexión con ello, hay que subrayar que los usos referenciales no han desplazado por completo a los "etimológicos", sino que existe un porcentaje muy minoritario 
nos permite aventurar mucho en esta dirección, puedo avanzar que la construcción impersonal con se, que en la zona "etimológica" española originalmente sólo podia combinarse con los pronombres le y les y referente animado ${ }^{4}$, se comporta en el área referencial sin esa restricción, siendo posibles $s e+l e, l a, l o$, en el singular, y se + les/los, las, en el plural, sin que en estas combinaciones cambien las pautas referenciales de empleo de los clíticos.

\section{LOS SISTEMAS DE TRANSICIÓN.}

Entre el sistema referencial en sus distintas variantes y las zonas en que los clíticos se utilizan de acuerdo con distinciones funcionales de caso, hay varias áreas de transición. Características comunes a todas ellas son la reorganización parcial del sistema pronominal "etimológico" por el contacto ejercido por el referencial inmediatamente vecino y que esa acomodación nunca implica la pérdida total de las distinciones de caso.

1. En la zona comprendida entre los rios Torío y Esla, al occidente, y el Cea, al oriente (sin que haya que descartar que el área se extienda más hacia el este), los usos referenciales del sistema (a), que ofrecen casi completa regularidad en el dativo, compiten todavía con los "etimológicos" en el acusativo: le y les alternan con lo y los en el acusativo referido a entes masculinos discontinuos, mientras que $l a$ es el pronombre mayoritario para referirse a entes femeninos continuos. La frecuencia con que alternan estas variantes pronominales en este sistema de transición occidental no es aleatoria y puede aclarar las vías por las que se extendió en León el sistema referencial a costa del "etimológico" 4 .

de casos en que el empleo de los clíticos no funciona de acuerdo con las pautas de análisis propuestas. Por el momento, no estoy en situación de aclarar si deben considerarse "restos" del sistema "etimológico" o parte del sistema referencial, ni qué factores (sintácticos o, quizá, pragmáticos) influyen en su aparición. En este sentido, Klein-Andreu ("Correction Strategies", art. cit.) ha estudiado cómo el laismo disminuye según avanza el nivel sociocultural de los hablantes con preferencia en los contextos de tres participantes. El último trabajo de Erica C. García ("Sincronización y desfase del leísmo y laísmo", art. cit.) investiga asimismo sobre el contexto sintáctico, el valor léxico del verbo y la naturaleza del referente que podrian favorecer la penetración del leismo y el lais$m o$ en el habla de estudiantes universitarios de Santiago, Oviedo, Salamanca, Valladolid y Madrid.

46 Esta situación original española es todavia la de gran parte de Hispanoamérica. Véase Studerus, "Impersonal se + lo(s)", art. cit., y Ramón Santiago Lacuesta, "'Impersonal' se le(s), se lo(s), se la(s)", Boletin de la Real Academia Española, LV, 1975, págs. 83-107 (esp. pág. 89, nota 23).

47 En los recuentos provisionales de mis datos, le es en el acusativo singular la forma preferida $(60 \%)$ frente a $l o(40 \%)$ para referir a los entes discontinuos masculinos, sin que la desmembración de ejemplos en animados e inanimados cambie esos porcentajes. En el plural, en cambio, el porcentaje de les frente a los parece superior con refe- 
Sistema (d) ${ }^{48}$ :

\begin{tabular}{|c|c|c|c|c|c|c|}
\hline \multirow{4}{*}{ ACUSATIVO } & \multicolumn{4}{|c|}{ SINGULAR } & \multicolumn{2}{|c|}{ PLURAL } \\
\hline & \multicolumn{2}{|c|}{ CONTABLE } & \multicolumn{2}{|c|}{ NO-CONTABLE } & MASCULINO & FEMENINO \\
\hline & masculino & femenino & masculino & femenino & & \\
\hline & le $\sim$ lo & la & lo & la & les $\sim$ los & las \\
\hline DATIVO & le & la & lo $\sim$ le & $\mathrm{la} \sim \mathrm{le}$ & les & las \\
\hline
\end{tabular}

Ejemplos de (d) ${ }^{4 y}$ :

Acusativo singular:

le $\sim$ lo: ¿cómo le matábamos? A cuchillo... hombre, claro, hay que sujetarlo... hay que lavarlo bien el cerdo. Lo lavamos ahora, no creas que entonces ... y con paja, pues le jamuscabas, y luego con un ladrillo, o una teja, lo rallabas bien rallao, y luego con

rentes animados $(75 \%)$ que con inanimados $(60 \%)$. La, las son los pronombres seleccionados para el dativo femenino en la inmensa mayoría de los casos (80\%), así como también lo es la en el acusativo $(85 \%)$ y en el dativo cuando el referente es femenino y continuo. Lo se emplea con exclusividad para referir a los continuos masculinos en el acusativo mientras que compite con le en el dativo. Nuestros datos coinciden parcialmente con los resultados de Luis Cortés Rodriguez, obtenidos del análisis del parámetro persona/cosa ("El uso de $l a(s), l e(s), l o(s)$ : variantes sociolingüísticas en el habla de la ciudad de León", Estudios de español hablado (Aspectos teóricos y sintáctico-cuantitativos), Instituto de Estudios Almerienses, 1992, págs, 105-118). En algunos aspectos, este sistema de transición occidental coincide en sus vacilaciones con el sistema referencial (c). En realidad, uno y otro representan la transición occidentál y la oriental al sistema referencial del norte, el (a). La comparación entre los usos pronominales en ambas áreas (oriente de León y oriente de Castilla) arrojaría probablemente vías de entendimiento sobre el morlo en que se produjo el avance de las confusiones y sobre el porqué de que no llegaran a generalizarse totalmente.

48 He encontrado el sistema de transición occidental en San Román de los Oteros, Cubillas de los Oteros, Villasabariego, Villarmún, San Cipriano del Condado, Cifuentes de Rueda, Quintanilla de Rueda, Cubillas de Rueda, Aleje, Manzaneda de Torío, Santa Colomba de Curueño y Palazuelos de Boñar. Probablemente es también el sistema de Villacidayo, a orillas del Esla, descrito por José Millán Urdiales: "en nuestra habla la diferencia se hace entre objetos individualizables - un carro, un arado, etc., cualquier objeto que existe como individuo dentro de su categoria-y los que no lo son, como por ejemplo el vino, el abono, el trigo, etc. : se dirá : sdónde echo el trigo ? - échalo ahí, pero bdónde pongo este costal? - ponle ahi [...]. También es corriente el laísmo: esta vaca no la gusta nada ir al monte. Ambos fenómenos se extienden al plural: estos garbanzos si no les cueces bien, no hay quien les coma; están aqui esas chicas - dilas que entren p'acá" (El habla de Villacidayo (León), Madrid, Anejo XIII del BRAE, 1966, pág. 164).

49 Ejemplos procedentes de Santa Colomba de Curueño y San Cipriano del Condado que fueron transcritos por José Ignacio Sanjuán Astigarraga. 
agua hirviendo, bien caliente, ... limpiarlo bien; el santo le sacan los jóvenes; y criaban el ternerín, si lo criaban; el horno le tengo alli ... y le arrojo el horno y allí cuezo las madalenas.

lo: se llevaba el trigo. te lo molian y luego, pues a amasar; los pementoneros traían el pimiento de allá, de Béjar, ... lo traían y lo vendian por aqui; en la montaña sí lo hacian, si, y lo seguirán haciendo a lo mejor (el queso).

$l a$ : pues matan al cerdo y hacen la morcilla, que esa no la conocerán; aquí se hacía la fiesta el catorce de septiembre... y ahora ya la pusieron pa'l primer domingo; y si es santa, la sacan las jóvenes; es que antes habia mucha mocedad y ahora no la hay; pues la voy juntando la nata en una sopera que tengo, y cuando me parece que tengo así, pa hacer un rollo curioso, pues cojo y la preparo, la hago ... si queréis verla, vos la enseño (la mantequilla); yo compro la leche, ... porque no debíamos comerla con nata y la desnato; hay quien tiene que comprarla porque no tiene quien se la traiga, yo toavía me la van trayendo (la leña); pa regar viene del río, ahora, pa gastar la gastamos de la fuente de ahí (el agua).

\section{Dativo singular:}

le: se mataba al cerdo, se le metía el cuchillo.

la : y otra chica, pues estuvo estudiando, ... la compró el padre un piso y está allí; hay quien la gusta coser, cose, pero hay quien no, no echa puntada, porque no la gusta.

le $\sim$ lo: el congrío lo cuezo, y luego le frío un ajo, una hoja de laurel, un trocito de pan, lo machaco todo, le quito el agua, le echo eso por cima y le echo un poquitín de harina que esté un poco más espeso el caldo; hacían un horno, una cosa redonda grande, lo tapaban con un poco hierba, y luego lo tiraban tierra encima.

le $\sim$ la: caliento la leche a treinta grados, le echo un poco de cuajina; se tenía la ropa antes mucho mejor lavándola eso, que ahora con las lavadoras. Mucho mejor. Porque la lavabas, la tendías al verde, la dabas dos regaduras, la volvías a sacar aquel jabón, la dabas otro, y tenías la ropa blanca como la leche.

\section{Acusativo plural:}

las: se hacian roscas de esas buenas, las hacía yo antes; se perdieron las viñas porque ya no las querían trabajar; traen truchas de una factoría..., se las echa ahí en el río. les los: pues yo tenía cuatro o cinco trillos, el año pasado les sacaron de una casa que teniamos allí arriba; [ $y$ comen tordos?] Hay quien dice que sí, ... pero no, yo nunca les comí; los chorizos, después que se hacen, hay que colgarles pa que se seque la tripa, ... ahí, pa la Rioja, les curan al aire y no necesitan calor; sí, sí les hay finos. [¿El qué hay finos?] Chavales pa pillar la trucha; pues aqui había muchos que les vendian, yo no les vendía, porque les criaba pa casa (los conejos); los bizcochos ... antes les hacíamos en moldes que teníamos; les lleva, comen allá, y por la tarde, les vuelve a bajar (a los niños que van al colegio); los huevos si los vendo ahora también; los filetes de merluza los frío; les tengo embotaos asaos en el horno, y tengo embotaos fritos, y tengo embotaos sin freir, y luego los cuezo (pimientos).

Dativo plural:

les: les daba el ayuntamiento equis dinero para la comida ... y después pol pueblo alante pedian, les daban chorizo, o huevos o... (a los quintos). 
las: las chicas ahora, si tienen que poner un botón, las cuesta trabajo; no ves que antes las vacas no las daban [de comer] como ahora ... y algunas habia que ayudarles con lo que pudiera, ... echándolas algo de harina, del centeno que cosechabas, eso se molía, se les echaba algo de harina.

2. La segunda zona de transición se sitúa al sureste y comprende al menos la esquina noroccidental de Ciudad Real, el oriente de Toledo y el occidente de Guadalajara. En esta área el empleo de los clíticos se gobierna por las distinciones casuales con una salvedad: la penetración del sistema referencial en el acusativo singular. La referencia pronominal en los contextos de acusativo singular parece funcionar conforme a esta regla: $l e$ es el pronombre para los masculinos animados, $l o$ el de los inanimados y $l a$ el del femenino. En los lugares más próximos al sistema "etimológico", le alcanza su máxima frecuencia con referentes personales; en cambio, cuando nos acercamos al sistema referencial, le se generaliza con todo tipo de referentes contables masculinos al tiempo que 10 se introduce progresivamente en la referencia a los continuos femeninos.

Sistema (e) ${ }^{\text {so }}$ :

\begin{tabular}{|c|c|c|c|c|c|}
\hline \multirow{4}{*}{ AcUSATIVO } & \multicolumn{3}{|c|}{ SINGULAR } & \multicolumn{2}{|c|}{ PLURAL } \\
\hline & \multicolumn{2}{|c|}{ MASCULINO } & \multirow[t]{2}{*}{ FEMENINO } & \multirow[t]{2}{*}{ MASCULINO } & \multirow[t]{2}{*}{ FEMENINO } \\
\hline & animado & inanimado & & & \\
\hline & le & lo & la & los & las \\
\hline DATIVO & le & le & le & les & les \\
\hline
\end{tabular}

Ejemplos de (e) ${ }^{51}$ :

Acusativo singular:

$l e:$ y si le pillaba, muchas veces tenía que hacer la vista gorda (el padre de la novia al novio); unos le enganchaban del rabo, ... le pillamos entre todos, entre 3 o 4 o 5 , que le tumbaban, le echábamos a la mesa (el cerdo).

so Reorganizan la referencia del acusativo singular de acuerdo con el sistema (e), o con alguna de sus dos variantes mencionadas, Madridejos, Lillo, Consuegra, El Romeral, Camarenilla, Recas (Toledo), Yebra, Uceda, Condemios de Abajo (Guadalajara), Puebla de don Rodrigo y Los Ballesteros (Ciudad Real). La proximidad con el área referencial explica la aparición minoritaria de laismo singular, de le referido a discontinuos masculinos y de lo para continuos femeninos.

si Los ejemplos proceden de Consuegra y de Lillo (Toledo) y debo su transcripción a María José González Arévalo. 
lo: pesaban un quilo de masa y lo tenian asi, hacian el pan redondo y lo ponian en un tablero; y si era hombre, lo llevaba asi (un cántaro con agua); el lomo lo embutian; el trabajo corporal única y exclusivamente lo llevaba el hombre; el trigo, así, tirándolo asi, con la mano por la tierra, lo iban sembrando tó a mano.

la : tenian que ir las mujeres con un cantarito aqui y traela de 200 o 300 metros, ... y estar allí un par de horas para cogerla (el agua); los fabricantes venian a comprala, ahora la arrojan porque no hay quien la compre (la lana); la tenemos buena la cabeza con los años que tenemos; ibas a sacarla a bailar (a la chica).

Dativo singular:

le: estaba el cochino en la pocilguera, venía el matador, le echaba un gancho al hocico y... a la mesa, a metele el cuchillo; a lo mejor el vino de Consuegra se lo llevan a Valdepeñas y le ponen la etiqueta que no es; y luego volvían otra vez a darle y asi hacían los chorizos (a la máquina de enchorizar); algunos le echan pimentón ... lo único que se le echa en mi casa a la morcilla; sí, hombre, mientras habian sido novios le habia dao, le había regalao a la novia; además de la iguala que tenemos del seguro social, luego tenemos que pagale un tanto al médico.

Acusativo plural:

los: hay que molerlos, y al molerlos, entonces ya se vuelve harina, igual que el trigo (los pitos); se sacaba hasta incluso los lomos, que en muchas ocasiones los embutían en unas tripas; los corderos, cuando se criaban, quitárselos y venderlos; viene un autobús o dos para distribuirlos (a los niños).

las: hombre, pues explotarlas en la cuestión del ordeño para la leche (las vacas); las ovejas las ordeñaban; hay un hombre arriba y ese hombre coge las espuertas y las vacia; se sembraban muchas y las vendian por ahi (las zanahorias).

\section{Dativo plural:}

les: no es como ahora, que a las niñas les dan de todo gratuitamente; comían hierba o les echabas de comer (a las ovejas); a los chicos les daban el pecho, y luego, cuando eran un poquito mayores, les dabas pues cocido con patatas.

3. La existencia viva del sistema de transición suroriental en el habla rural tiene muchísimo interés, porque permite asegurar que el famoso sistema de compromiso del "estándar" (con le en los contextos de acusativo singular referido a personas masculinas) no es sólo una creación de los gramáticos y de los hablantes cultos, sino la norma que gobierna el uso en una zona de Castilla. Asimismo, su documentación actual viene a explicar los datos hallados en textos medievales y modernos en que se observaba leismo personal en el singular con exclusión de otras confusiones ${ }^{52}$. El origen de este sistema

\$2 Véanse Keniston (The Syntax, pág. 64), Lapesa ("Los origenes", págs. 527-540), Marcos (Estudios sobre el pronombre, págs. 124-159), Echenique ("El sistema referencial", págs. 131-152) y López Bobo ("Sobre el leísmo", págs, 353-358, y "Laísmo y loísmo", págs. 599-605). Tiene interés anotar que el uso pronominal de Cervantes en el Qui- 
le transición no está claro ${ }^{53}$, pero su testimonio parece avalar la primitiva via de aparición de las confusiones en el sistema "etimológico" defendida tradicionalmente, que achaca el origen del leismo a la extensión del dativo latino a todos los contextos acusativos con referentes personales. Sin emlargo, hay que matizar que la hipótesis sólo resulta adecuada para explicar la gestación de este sistema de transición si se invierte su argumentación. En este sistema de transición el leísmo restringido a referentes masculinos personales o animados no representa el origen de los usos referenciales, sino que, por el contrario, es el fruto de haber reanalizado el sistema "etimológico" ante la presión en avance del sistema referencial. Ello explica que la extensión del dativo le al acusativo personal se haya visto favorecida exclusivamente en los referentes masculinos y frenada, en cambio, en los femeninos, ya que en el sistema referencial inmediatamente vecino se empleaba le para los primeros y la para los segundos.

Por último, hay que añadir que el sistema de transición suroriental también contribuye a aclarar las frecuencias tradicionalmente anotadas en las

jote se adlapta perfectamente a los parámetros de este sistema de transición. Cervantes, alcalaino, es leísta en singular para personas masculinas, en grado ligeramente menor para "cosas" (repartiendo con lo el total de usos) (= le para contables, lo para nocontables), laísta en un porcentaje mínimo (10\%) y "etimológico" en el plural. Véase Demmer y Wright, “A frequency study”, art. cit., pág. 162.

ss Tampoco es todavía obvio el nacimiento del sistema de compromiso o del "estándar", utilizado por los estratos socioculturales más altos de toda la península con variable intensidad Podria haber surgido de la adopción, y posterior generalización, por parte de la norma culta, del sistema de transición suroriental hablado popularmente en las cercanias de Madrid (o quizá incluso en parte de la provincia misma); pero también podría haberse or:ginado con independencia del habla autóctona de la zona, que parece ser referencial. Recuérdese que el sistema referencial (b) tiene vitalidad en el habla rural de, al menos, el noroccidente de Madrid (cf. supra, págs. 87-90). Por otro lado, los recuentos estadísticos realizados por Moreno et al., "Anotaciones", art. cit, que se hic:eron diferenciando los objetos referidos a persona de aquellos que tenían por referente tanto animales como cosas, concluyen que el leismo y el laismo están generalizados en el habla popular madrileña en un porcentaje entre el $50 \%$ y el $60 \%$, mientras que el loismo apenas alcanza el $20 \%$. "No existen diferencias significativas entre los usos de estos pronombres en singular y en plural" (pág. 104, nota 7), lo que parece indicar que el sistema generalizado en Madrid es una prolongación del referencial burgalés y segoviano. En cambio, el uso de la lengua culta madrileña sabemos que responde, con ligerísimas desviaciones, al sistema "estándar" de compromiso (cf. Quilis et al., Los pronombres ' $l e^{\prime} ' \mathrm{l} a^{\prime} y^{\prime} ' \mathrm{l} o^{\prime}, o p$. cit.). Por ello, quizá el origen del sistema propio de la lengua estándar habría que buscarlo en un reanálisis parecido al que tuvo en la lengua popular, pero realizado, según señaló Klein-Andreu. por los individuos que regulan el uso normativo del idioma: gramáticos que, como Salvá o Bello, observaban los usos referenciales sin compartirlos ni comprender las pautas de su comportamiento lingüístico. El estudio del sistema pronominal originario de Madrid será determinante para entender el proceso creativo de este sistema de compromiso. La capital del reino parece estar situada justo en el punto de colisión de varios frentes de ola : aquel en que choca el sistema referencial "abulense-toledano" con el sistema de transición "alcarreño", e incluso, con el sistema confundidor hablado al norte de la provincia, en Segovia y en Burgos. 
desviaciones pronominales: si a los datos de las zonas netamente referenciales, en que ya vimos que el leísmo personal en el singular resultaba más elevado que el de "cosa", unimos los de esta área de transición, que ha generalizado le sólo en los contextos de acusativo masculino animado, es obligado que la tendencia al leismo personal resulte notablemente incrementada en oposición al leismo de "cosa". El testimonio de este sistema también hace posible entender la menor extensión del laímo respecto al leismo personal, ya que en el femenino se distingue el caso.

\section{Los sistemas asturiano y cántabro.}

El origen de la distinción entre lo continuo y lo discontinuo que explica la alternancia entre $l e$, la y lo en los territorios castellanos debe buscarse en el dominio lingüístico del astur-leonés centro-oriental, área en que tienen validez en la sintaxis esas distinciones ${ }^{54}$.

1. En la zona central y oriental de Asturias, esto es, en los territorios comprendidos entre el río Nalón en Asturias y el Saja en Cantabria existe un sistema autóctono para los pronombres átonos de acusativo singular basado en el rasgo de continuidad/discontinuidad del referente ${ }^{55}$. La marca gramatical que indica la continuidad se sobrepone en el pronombre (y en los adjetivos) a la de género morfológico, anulándola ${ }^{56}$. Conviene hacer notar

34 La idea de extender la distinción $+/$ - contable al análisis del leísmo castellano fue ya enunciada por Jesús Neira, "La oposición 'continuo' / 'discontinuo' en las hablas asturianas", Estudios ofrecidos a E. Alarcos Llorach, III, Oviedo, Universidad, 1978, págs. 255-277 (esp. pág. 276), y Francisco García González, “/le (lu), la, lo (lu)/", páginas 352-353. Klein-Andreu asume igualmente que el origen de la pertinencia de esa distinción debe buscarse en la influencia que ejerció en época primitiva el astur-leonés centro-oriental sobre el castellano de Cantabria, "Distintos sistemas", art. cit., págs. 5-7 y $9-10$.

ss Todo el occidente asturiano desconoce el sistema del centro y oriente empleando lu $\sim l o, l a, l u s \sim l o s$, las (u otras variantes tsu, tsa) para el acusativo e $i$, is ( chi, tsi, tse, yi) para el dativo. Véase Manuel Menéndez García, El cuarto de los valles (un habla del occidente asturiano), Oviedo, IDEA, 1963, págs. 193-194; Ana María Cano González, El habla de Somiedo (occidente de Asturias), Verba, anexos 4-5, Universidad de Santiago de Compostela, 1981, págs. 124-129; Olga Josefina Díaz González, El habla de Candamo (aspectos morfosintácticos y vocabulario). Oviedo, Universidad, 1986, páginas 31-33, y Lorenzo Rodríguez Castellano, Aspectos del bable occidental, Oviedo, IDEA, 1954, págs. 202-208.

s6 Por ejemplo: vi el hombre > vilu; vi la muyer > vila; pero: bebi la leche > bebilo; bebí el vino $>$ bebilo. En los adjetivos: el pic friu; la casa fría; el carbón negro; la madera seco. Véase Neira, "La oposición 'continuo'”, art. cit., págs. 261-264, quien ha probado que no existe en los bables de Asturias oriental, central y del occidente de Cantabria una oposición morfológica entre masculino, femenino y neutro, como pensaba Dámaso Alonso ("Metafonía, neutro de materia y colonización suditaliana en la 
que la reorganización de la referencia pronominal en el acusativo singular del sistema asturiano no se acompaña de la indistinción de $\operatorname{casos}^{5}$ :

Sistema (f):

\begin{tabular}{|c|c|c|c|c|c|}
\hline \multirow{4}{*}{ ACUSATIVO } & \multicolumn{3}{|c|}{ SINGULAR } & \multicolumn{2}{|c|}{ PLURAL } \\
\hline & \multicolumn{2}{|c|}{ CONTABLE } & \multirow[t]{2}{*}{ NO-CONTABLE } & MASCULINO & FEMENINO \\
\hline & masculino & femenino & & & \\
\hline & lu & la & lo & los & les/las 58 \\
\hline D.TTIVO & & $\mathrm{i}$ & & yo: & \\
\hline
\end{tabular}

península hispánica" [1961], en Obras Completas, I, Madrid, Gredos, 1972, págs. 147213, esp. págs. 173-189). El llamado "neutro de materia" es, en realidad, un morfema que aparece para referirse a la categorización sintáctica como continuo del ente referido, el cual nunca deja de ser masculino o femenino desde el punto de vista léxico; lo que sucede es que la marca de género se anula ante la de continuidad (igual que la de número plural puede eliminar la de género: $-o+-a=-o s$ ). Para un análisis global de las manifestaciones sintácticas de este fenómeno, véase Francisco García González, "E1 neutro de materia", Homenaje a Alonso Zamora Vicente, II, Madrid, Castalia, 1988, págs. 91-105. En cuanto a los supuestos sustantivos "neutros" en -o del asturiano y sobre una nueva interpretación del origen de la alternancia $-u /-o$ en Asturias, véase el último artículo de Neira, "Función y origen de la alternancia $-u /-o$ en los bables centrales de Asturias", $B R A E, \mathrm{LXXI}$, 1991, págs. 433-454.

57 Junto a esta versión más popular del sistema asturiano, propia del medio rural (f), existe otra que se encuentra en los hablantes más sometidos a la presión del castellano (f'), pero ambas, aunque cambian la forma de los pronombres, mantienen esencialmente las mismas distinciones gramaticales. Sólo se percibe la peculiaridad del sistema (f'), que coincide aparentemente con el "etimológico", en el empleo de lo para sustantivos femeninos no-contables:

(f') :

\begin{tabular}{|c|c|c|c|c|c|}
\hline \multirow{4}{*}{ ACI'SATIVO } & \multicolumn{3}{|c|}{ SINGULAR } & \multicolumn{2}{|c|}{ PLURAL } \\
\hline & \multicolumn{2}{|c|}{ CONTABLE } & \multirow[t]{2}{*}{ NO-CONTABLE } & \multirow[t]{2}{*}{ MASCULINO } & \multirow[t]{2}{*}{ FEMENINO } \\
\hline & masculino & femenino & & & \\
\hline & lo & la & lo & los & las \\
\hline DATIVO & & le & & & \\
\hline
\end{tabular}

Han descrito el sistema popular María Josefa Canellada (El bable de Cabranes, Madrid, 1944, Anejo XXXI de la RFE, pág. 23), Jesús Neira Martínez (El habla de Lena, Oviedo, IDEA, 1955, pág. 47), Jesús Âlvarez Fernández-Cafiedo (El habla y la cultura popular de Cabrales, Madrid, CSIC, 1963, pág. 50) y Celestina Vallina Alonso (El habla 
Ejemplos de (f) :

Acusativo singular:

Iu : a Bernardu lleváronlu preso; el paquete olvidélu.

la: a Maria tú no la conoces; a la yegüa viémosla en el monte; la piedra no la llevanta.

lo: el café vendialo en granu; la herba primero hay que segalo, después atropalo, marralo; aqui en pueblu, la leche no lo vende naide.

Dativo singular:

i: dixoi a él; ¿cuántu i costaría esa vaca?

Acusativo plural:

los: Hace un año que no los veo (a tus padres); ¿no los fries? (los frisuelos).

les/las: Encontréles camino de tu casa (a ellas); les que no sirvan, tírales (las peliculas); ¿cómo las arreglastes, hombre? (las sardinas); la corcia pariú dos cabritas y ya las comiú la gocha.

Dativo plural:

yos: me alegro que no yos den el título universitario; van a subiyos el seguro (a los coches).

2. El sistema (f) se prolonga en el habla vernácula del occidente de Cantabrid con una única diferencia, los dativos $i$, yos, se sustituyen por $l i \sim l e$,

del sudeste de Parres (desde el Sella hasta el Mampodre), Oviedo, 1985, págs. 127-130), y ambos sistemas Carmen Díaz Castafión (El bable de "El Cabo de Peñas" (Contribución al estudio del bable central), Oviedo, IDEA, 1966, págs. 171-73, 176-78, y "Algo sobre sintaxis del asturiano", $R S E L, 6,1976$, págs. 363-367), Marta Pérez Toral ("El sistema pronominal átono de tercera persona en el habla de Oviedo", Archivrm, XXXVII-XXXVIII, 1987-88, págs. 553-571, esp. págs. 556-566), y Francisco García González ("Los pronombres personales en el oriente de Asturias", Estudios y trabayos del Seminariu de llingua asturiana, II, Universidá d'Uvieu, 1979, págs. 47-56, y "/le (lu), la, lo (lu)/", art. cit., págs. 347-349). El sistema (f) está documentado, pues, en Cabranes, Lena, Cabrales, la región del Cabo de Peñas, Meluerda (Ribadesella), Caño, San Martín de Bada (limite con Parres) y Elgueras (Cangas de Onís), Benia, Gamonedo y Babia de Abajo (en Onís), Vibaño y Porrúa (Llanes), y Sotres y Tielve (Cabrales). Por nuestras encuestas lo hemos confirmado en Arenas de Cabrales y en Parres. El sistema ( $\left.f^{\prime}\right)$ en Oviedo y el habla culta de la parte central y oriental de la provincia. En la montaña leonesa oriental, en Oseja de Sajambre, el sistema es el mismo con la diferencia de que a veces $l u>l o$ (véanse los textos dialectales reproducidos por Ángel Fernández González, El habla y la cultura popular de Oseja de Sajambre, Oviedo, IDEA, 1959, págs. 59 y 74-98).

so La forma les es la propia del bable central; las, la del oriental.

so En Cabrales los pronombres de Dativo presentan otras variantes: singular, $i, y e$, yi; plural, yos, yes. 
lis $\sim$ les y aparece el pronombre de dativo se, que no existía en Asturias. Este sistema, que llamaré (g), aparece documentado ya en los concejos más orientales de Asturias y se extiende por el occidente de Santander, conservándose especialmente en los valles altos de los ríos Deva, Nansa y Saja ${ }^{60}$ :

Sistema (g):

\begin{tabular}{|c|c|c|c|c|c|}
\hline \multirow{4}{*}{ ACUSATIVO } & \multicolumn{3}{|c|}{ SINGULAR } & \multicolumn{2}{|c|}{ PLURAL } \\
\hline & \multicolumn{2}{|c|}{ CONTABLE } & \multirow[t]{2}{*}{ NO-CONTABLE } & \multirow[t]{2}{*}{ MASCULINO } & \multirow[t]{2}{*}{ FEMENINO } \\
\hline & masculino & femenino & & & \\
\hline & lu & la & lo & los & las \\
\hline DATIVO & & $\mathrm{li} \sim \mathrm{le}$ & & lis & les \\
\hline
\end{tabular}

Ejemplos de (g):

Acusativo singular:

lu: da lástima segarlu (un prado); lu mataron a tiros (un oso); hay que seguirlu (un hombre).

In : (a Maria) la conocen; (la osa) tamién la matamos.

$l o$ : hay que venderlo (el ganado); para hilarlo mejor (la lana).

Dativo singular:

le: dali sidra, dáselo; li dijo que trajiera un pan.

60 El sistema (g) está descrito por García González ("El leísmo en Santander", art. cirt., págs. 89-90; "Los pronombres personales", art. cit., págs. 53-55; “/le (lu), la lo (lu)/", pág. 347) y Ralph Penny (Estudio estructural del habla de Tudanca, Tübingen, Max Niemeyer, 1978, págs. 80-82). Estos autores lo encuentran en Asturias en Alles y Pastorias (Peñamellera Alta), Panes, Alevia y Narganes (en Peñamellera Baja) y La Franca, Boquerizo y Pimiango (en Ribadedeva); en Cantabria, de acuerdo con Ralph J. Penny ("Esbozo de un Atlas de Santander", Lingüistica española actual, VI, 1984, páginas 123-181, esp. 170-171), este sistema es el originario en Enterría, Caldas, San Pedro de Bedoya, Lerones, Pechón, Cades, Bustriguado, Rozadío, Tudanca y Tresabuela, aunque García González reduce su conservación actual a los valles altos del Deva, Nansa y Saja. Los datos extraídos de mis propias encuestas me indican que el sistema (g), que debe percibirse de marcado carácter dialectal, está dejando paso en el habla popular del occidente cántabro al sistema general de Cantabria, el sistema (h). Sólo he encontrado el sistema (g) en Alles, Para (Peñamelleras Alta y Baja) y Linares (junto a La Hermida) y en esos lugares lu (lo) competía ya con le. Véase infra, nota 63. 
Dativo plural:

les: lis quitaron las botas, se las quitaron.

3. En el habla general de la mayor parte de Cantabria, desde la cuenca del río Deva hasta la del Aguëra, aparece una pequeña variación formal sobre el sistema $(\mathrm{g})$, pero de gran importancia, que consiste en que la forma propia del acusativo masculino contable $l u$ se reemplaza por la forma $l e^{61}$. Encontramos, aqui, por vez primera, leismo, empleo de $l c$ (o con una vocal más cerrada $l i$ ) como única forma para el acusativo y dativo masculinos cuando el referente es discontinuo. Aunque en el sistema cántabro (h) se produce sincretismo en la forma $l e$, conviene subrayar que ello no implica que haya confusión entre el dativo y el acusativo ${ }^{62}$ :

Sistema (h) ${ }^{\mathbf{3}}$ :

\begin{tabular}{|c|c|c|c|c|c|}
\hline \multirow{4}{*}{ ACUSATIVo } & \multicolumn{3}{|c|}{ SINGULAR } & \multicolumn{2}{|c|}{ PLURAL. } \\
\hline & \multicolumn{2}{|c|}{ CONTABLE } & \multirow[t]{2}{*}{ NO-CONTABLE } & \multirow[t]{2}{*}{ MASCULINO } & \multirow[t]{2}{*}{ FEMENINO } \\
\hline & masculino & femenino & & & \\
\hline & le & la & lo & los & las \\
\hline DATIVO & le & le & le & les & les \\
\hline
\end{tabular}

61 Según creen Ralph Penny (El habla pasiega: Ensayo de dialectoloyia montañesa, London, Tamesis, 1969, pág. 114) y García González ("El leísmo en Santander", art. cit., págs. 91-92), esa sustitución habría sido quizá favorecida por haberse oscurecido la vocal del pronombre para el acusativo no-contable $l o>l u$ en la zona cántabra. En su opinión, las causas de que se reemplazase $l u$ por $l e$ deben buscarse en una reorganización del sistema "para mantener diferenciados los valores de masculino y neutro, de relevante importancia en las estructuras del dialecto".

*3 García González ("E1 leísmo en Santander", págs. 90-94; “/le (lu), la, lo (lu)/", págs. $347-348$ ) ha descrito el funcionamiento del acusativo singular en este sistema, y en otros que se acercan progresivamente al castellano estándar mediante la paulatina renuncia a sus rasgos distintivos ("El leísmo", págs. 92-100). El más generalizado en el habla culta santanderina es aquel en que $l o$ pierde la capacidad de referir a femeninos nocontables, resultando el siguiente paradigma: le, masculino contable, la femenino, lo masculino no-contable. Sus trabajos no aclaran, sin embargo, si el leismo del acusativo masculino va acompañado de la extensión de $l a$ al dativo femenino y de lo como forma de dativo en la referencia a entes continuos. Tampoco informa del comportamiento de los clíticos en el plural. De acuerdo con nuestros datos, el sistema mayoritariamente hablado en Cantabria emplea las formas "etimológicas" tanto en contextos de acusativo plural como de dativo (singular o plural).

6 De acuerdo con nuestros datos, el sistema (h) se emplea con regular vitalidad en el occidente cántabro: en los valles del Deva (tanto en la vertiente asturiana, Colombres, 


\section{Ejemplos de $(\mathrm{h})^{64}$ :}

Acusatizo singular:

le: alli tiene un tanque frigorifico, aqui también le teniamos; el carro le tengo, ya no le usan, porque resulta que se han hecho todos a un tractor: el jamón había que salarle y tenerle tres días debajo de una piedra ... y después le salábamos con salnitro ... y eso hay que untarle bien y después ponerle a curar; el marido mío no se atrevió nunca a matarle y buscábamos un vecino y le mataba... entonces le chamuscamos con unos helechos y después abrirle (el cerdo); unos le llamaban pa sacar piedra pa una cabaña, otros le llamaban pa hacer cosas (al marido).

la : yo me acuerdo que llevábamos dos cacharras, una la traia en la cabeza; después, esa cerda la engordábamos pa matarla; cuando necesitamos una docena de huevos, la compramos y se acabó el tinglao.

lo: después vino una fábrica que se llama "La sal" a recoger leche y se puso él a recogerlo y lo tenía que bajar en ese puente; cuando venía la cosecha de la hierba, pues a la hierba a curarlo y a traerlo pa casa pa el invierno; en una cacharra de 10 litros o así le quitábamos la nata por encima. lo reuníamos y después aquella nata lo machacábamos y salía la mantequilla ... y teníamos que venderlo pa traer otras cosas; el tocino nada más era eso, salarlo y tenerlo una temporada en sal y después lo sacábamos y lo adobábamos un poco; se llevaba al molino el maíz y allí lo molian y se traía después en harina.

Dativo singular:

$l e$ : no han podido darle estudios porque estaba lejos para ir de aquí (a la nieta); esa dijo que no le gustaban mucho las vacas y marchó a servir a Santander; le echábamos el macho y tardaban, me parece que tres meses (a la cerda); se cuece arroz, se le echa pimienta, perejil, cebolla ... y eso hay que echarle (a la morcilla); el hijo mío cuando fue a Barcelona no le gustaban alli las morcillas porque no les echaban arroz.

como cántabra, Lebeña, Mogrovejo, Valdeprado, Ledantes y Frama), Nansa (Pechón, Santillán, Cosío, Tudanca), Saja (Lamiña, ayto. de Valle de Cabuérniga), como en los municipios de Roiz (La Canceda) y Novales. El sistema (g), descrito por García González ("Los pronombres personales", art. cit., págs. 53-55) y por Penny (El habla de Tudanca, págs. 80-82, y "Esbozo", págs. 170-171) como originario de esta área, ha retrocedido dejando el paso al sistema (h). Lo mismo sucede en el centro y occidente cántabros: en los valles de los ríos Besaya (Silió), Pas (Vega de Pas, Santiurde, San Vicente de Toranzo, Zurita), Pisueña (Tezanos, Argomilla), Miera (Rubalcaba), Asón (Arredondo, Rozas), y en los municipios de Solórzano (Portillo) y Alto Guriezo (Landeral). Este sistema también aparece en algunas localidades del noreste de Burgos, cercanas a Cantabria y situadas entre el sistema referencial (tipo c) y el área norburgalesa de influencia lingüística navarra: Quintana de los Prados, Quintanilla de Valdebodres. Leciñana de Mena, San Cristóbal de Almendres. En cambio, el sur de Cantabria no participa ya del sistema (h).

a Los ejemplos proceden de Rozas (junto a Ramales, Cantabria) y debo su transcripción a Rocío Barriopedro Macéin. 
Acusatizo plural:

los: los huevos no los comiamos todos; yo los picaba con la máquina, hay quien los deja enteros y luego los quitan (los ajos); yo en casa los tuve, es que no fui nunca a médico ni nada y los tuve la mar de bien (a los hijos).

las: teníamos que andar cuidándolas (a las vacas); tenía ya unas pocas gallinas y dije, mira, las vamos a quitar; después abrirle y ya sacar las morcillas, lavarlas.

Dativo plural:

$l e(s)$ : le traiamos pienso y cuando no, también teniamos que comprar, porque no nos alcanzaba la hierba (a las vacas): nacian y a los pocos dias había que darles un poco de leche a los hijos (a los cochinillos).

4. Aunque el sistema cántabro (h) mantiene básicamente las distincio nes casuales, al igual que los sistemas astur-leoneses (f) y (g), en los valles de los ríos Besaya, Pas, Pisueña y Miera (zona centro-oriental de Cantabria) aparecen modificaciones de gran trascendencia. En estas zonas los pronombres de acusativo la, las y lo se extienden al dativo con referente femenino y continuo. respectivamente, $y$ el leismo parece estar penetrando en el plural ${ }^{65}$. Aunque la frecuencia de estas alteraciones es muy inferior a la de los usos "distinguidores" del sistema cántabro más generalizado ${ }^{*}$, su presencia ilustra perfectamente el punto de particla del desarrollo del sistema referencial.

6s Penny anota leismo y laismo en el valle del Pas (San Pedro de Romeral, Vega de Pas, Selaya, San Roque de Riomiera) (El habla pasiega, op. cit., págs. 113-114 y 154, 156). A estas confusiones Clara Maria de Vega añade el empleo de lo como pronombre de dativo con referentes continuos ("El sistema pronominal átono en Cantabria", Estudios filológicos en homenaje a Eugenio de Bustos Tovar. II, Universidad de Salamanca, 1992, págs. 947-955, esp. 951-952). En mis encuestas he detectado estas confusiones incipientes en Tezanos, Argomilla, Portillo de Solórzano, Zurita (la, las), Frama, San Vicente de Toranzo (la), Rubalcaba (las), Vega de Pas, Santiurde (lo), Silió, Santiurde de Reinosa, Reinosa (la, las, les) y Barrio (junto a Paracuelles) (les). Nótese que la aparición de les se registra preferentemente en el sur de Cantabria, zona que ya empieza a participar de los usos propios del sistema referencial.

* De acuerdo con los recuentos parciales de mis datos que he podido realizar, la, las penetran aproximadamente en un $30 \%$ de los usos del dativo femenino. En cambio. el empleo de les como acusativo masculino y de lo como dativo para continuos parece estar mucho más restringido. Los recuentos pronominales de Marcos Marín sobre Peñas arriba (1894) de Pereda, aunque realizados sobre otros parámetros de análisis, permiten reconstruir un sistema semejante : Pereda es leísta casi exclusivo de persona y cosa masculina (= usa le para masculino contable), y lo para "OD colectivo y neutro" (= lo para no-contables): levemente laísta en el singular ( $l a$ alterna con le en una proporción 1/3), y escasamente leísta en el acusativo plural (les/los aparecen en una proporción 1/10). Véase asimismo el ejemplo lo para dativo neutro de Pereda: "no lo prestábamos grandísima atención" (Estudios sobre el pronombre, op. cit., págs. 241-248). En cambio, inexplicablemente, De Vega juzga general el empleo de lo como dativo y mayoritarios los de la, las como dativos y de les como acusativo ("El sistema pronominal átono", art. cit., págs. 951-952). 
La transición del sistema utilizado hoy en la zona pasiega al referencial vivo en Castilla se conserva en las comarcas rurales y montañosas del sur de Cantabria y las zonas vecinas del noroccidente de Burgos. En esos territorios, aunque la, las y lo siguen compitiendo con le, les como pronombres de dativo y les con los como forma de acusativo, según sucedia en las comarcas cántabras del norte, la proporción de usos confundidores y distinguidores se invierte, triunfando abiertamente $l a$, las como dativos, mientras que, sin obtener tanto éxito, les lucha por desplazar a los del acusativo y lo a le del dativo referido a entes continuos ${ }^{67}$. En esta zona del norte de Castilla la generalización de les acusativo en detrimento de los sólo se hace perfecta alli donde nace el río Pisuerga, entre Reinosa y Cervera de Pisuerga ${ }^{\star 8}$, comarca que quizá pueda considerarse creadora del sistema referencial del tipo (a).

V. El sistema pronominal del romance. hablado en el. País Vasco.

En el romance hablado en el Pais Vasco y en el norte de Navarra se emplean los pronombres átonos de tercera persona de acuerdo con reglas sintácticas completamente distintas de las que regulan las diversas soluciones referenciales de Castilla y del área cántabro-astur. El origen de estos usos, de importancia vital para comprender la génesis del sistema referencial, debe buscarse, sin duda alguna, en el contacto secular del español con el eusquera.

1. El habla de los bilingües cuya primera lengua es el eusquera (y con un dominio escaso del castellano) se caracteriza por suprimir sistemáticamente los clíticos de acusativo ${ }^{69}$. T.a elisión afecta a todo tipo de referentes, ani-

67 Esa penetración de les en el acusativo acaba por originar la aparición de los como pronombre de dativo. El reducido porcentaje de los dativo, frente al voluminoso que llega a obtener les acusativo, tal como los encontramos en el sistema (c), nos revelan la llegada tardía de los a ese contexto sintáctico. En Ruanales, Arroyal, Reinosa (Cantabria), Virtus, Montoto de Bezana, Covanera, Orbaneja del Castillo, Población de Arreba (Burgos) aparecen ya las confusiones en la forma propia del sistema referencial (c).

os En esta área he registrado el sistema referencial de tipo (a) en Mata de Hoz (Cantabria), Nava de Santullán, Ligüerzana y Lorilla (Palencia).

60 La supresión se ha explicado argumentando que en vasco se integran como morfemas de la raíz verbal (Mikel Zárate, Influencias del vascuence en la lengua castellana a través de un estudio del elemento vasco en el habla coloquial de Chorierri-Gran Bilbao, Bilbao, La Gran Enciclopedia Vasca, 1976, pág. 58; Hernán Urrutia Cárdenas, “El español en el País Vasco: peculiaridades morfosintácticas", I.etras de Deusto, 40, 1988, págs. 33-46, esp. 36-37, y María Teresa Echenique Elizondo, Vascuence y romance, "Lecciones de lingüística y didáctica del español", 11, Logroño, Gobierno de La Rioja, 1992, pág. 14). Allí donde el español entra en contacto con lenguas que también carecen de clíticos, como en el caso del quechua y del guaraní, se registra idéntica elisión: Véase Kany, Sintaris hispanoamericana, pág. 148; Toscano, El español en el Ecuador, págs. 202-203; Usher, “Castellano paraguayo”, pág. 53. 
mados o inanimados, singulares o plurales, masculinos o femeninos, continuos o discontinuos, y también al lo neutro. En cambio, rara vez se suprimen los pronombres de dativo. que pueden aparecer en la tercera persona reducidos at una forma única: $l e^{70}$.

Sistema (i)

\begin{tabular}{lllllllll}
\hline acusatrvo & $\ldots$ & $\ldots$ & $\ldots$ & $\ldots$ & $\ldots$ & & $\emptyset$ \\
Uatrvo & $\ldots$ & $\ldots$ & $\ldots$ & $\ldots$ & $\ldots$ & $\ldots$ & $\ldots$ & le(s) \\
& & & & & & & &
\end{tabular}

Ejemplos de (i) ${ }^{n}$ :

tcusativo:

La gallina, pues ya, cuando era mayor, [la] comías en casa; tienes alli una mujer que es viuda y no queremos que [la] trates mal ieh?; cuando me tocaba guardia, me [la] solia hacer uno de Briviesca; todo lo que tenias aqui ya [lo] tenías vendido; y eso z por qué [lo] hacen?; yo tenia en Elorrio un piso..., antes de venir aquí [lo] tenía cogido, ya sabia yo que íbamos a casar y ya [lo] tenía cogío; antes no había esa cosa de autobuses, yo [lo] he tenido cinco años interno en Universidad de Deusto ... un año que no podía entrar, [lo] tuve donde la prima y luego cuatro años allí en colegio, en Deusto (al hijo); también tienes pan de borona, [lo] tienes vendiendo, y semana pasada también [lo] trajo mi mujer de Durango y [lo] comimos en casa; ni merece la pena de guardar[la] hasta que venga el trapero, ... yo [la] tiré a la basura, por cincuenta pesetas que vas a tener ¿dónde [la] vas a tener? (la lana); ahora, como hay congeladores, [los] metes a un congelador en bolsas y ya está (los chorizos); cogemos las vainas en la huerta, [las] llevamos a casa .... cuando [las] echas al puchero, "hirve", cuando está hir-

70 Desconozco los motivos, que probablemente haya que buscar en la estructura sintáctica del eusquera, por los que la omisión afecta casi exclusivamente a los objetos acusativos. Los pocos ejemplos en que encuentro omitido el pronombre de dativo se reducen a estas tres situaciones: a) $\mathrm{El}$ argumento nominal que recibe caso dativo está presente en la frase y su duplicación por el pronombre $l e$ no parece resultar necesaria: "a esta [le] dije", "echando [le] bombas a nuestro caserio" (Mundaca), "los hijos antes [les] cogían a los padres más, más respeto" (Apatamonasterio), "veías una persona mayor, te apartabas y [le] cedías el asiento" (Galdácano). b) El verbo rector es pegar "dar golpes", que quizá no rija dativo en vasco: "y luego con un palo pegar[les]" (a las alubias) (Mundaca), "y [le] pegabas, ponias una cara un poquito alta, y [le] pegabas" (a un bote) (Apatamonasterio). c) El verbo rector es dar, que en la mayor parte de sus apariciones no suprime el pronombre de dativo: "podias dar[les] harina" (a los cerdos) (Mundaca), "dando[les] de comer, hierba y algo de pienso" (a los conejos), "dar[le] vuelta tú en la mano" (a la máquina) (Apata).

71 Los ejemplos proceden de una encuesta realizada en Apatamonasterio (Vizcaya). Debo su transcripción a Gregorio de Lucas Rubio. Para la mejor comprensión de los ejemplos, incluyo entre [ ] los pronombres omitidos. Debo agradecer aquí al profesor Patxi Goenaga, de la Universidad del Pais Vasco, su amabilidad al facilitarme la entrevista de informantes, tanto bilingües, de medio urbano (Galdácano), rural (Apatamonasterio) y costero (Mundaca), como monolingües originarios de Las Encartaciones. 
viendo, cinco minutos y fuera, [las] echas encima de la mesa..., cuanclo están secas, [las] metes en la bolsa, al frigorifico.

Dutio's:

Ibas al ayuntamiento y le dabas conocimiento al ayuntamiento, cómo ibas a matar; ya sahemos dónde está el veterinario y las muestras le [se las] llevamos al veterinario, que ya $[\mathrm{lo}]$ conocemos, ... le llevamos las muestras, le damos el número de teléfono; todo se pica, se le quita el piel, cuando está quemao, pues es fácil quitar[la] (al cerdo); hace dos años estuvo aqui una chica... con los jubilaos dando una charla de cómo hay que congelar, y yo le pregunté el cabrito y el corderu a ver cuánto tiempo puede estar en el congelador; suelo traer leche ... y le echas una cucharadilla de estas, de café; pa mí. antiguamente nosotros también metiamos puerro, pero no le metemos más que cebolla y las grasas del cerdo y sangre, nada más (a las morcillas); si “quiés" algo ordeñar, tienes que darle[s] pienso (a las vacas); ahora, sin embargo, los que vendian leche han estao vendiendo, pa no tener vacas lecheras le[s] han dao el dinero y han puesto vacas de carne.

2. Según avanza el aprendizaje del español, los bilingües comienzan a emplear pronombres en contextos acusativos. En un primer momento, y siempre conviviendo con la solución mayoritaria sin pronombre, se emplea $l e(s)$ como única forma pronominal de acusativo ${ }^{72}$. Es evidente que este uso exclusivo de $l e(s)$ resulta de haber extendido la forma del dativo al acusativo ante la dificultad que experimentan los bilingües para dominar el género en español, categoría inexistente en su lengua materna ${ }^{73}$. Aunque se dan ejem-

12 Este uso ya había sido percibido por García González, que recogió los ejemplos siguientes en un área no-bilingüe, I.as Encartaciones: "Hemos venido a visitarle a Terc (Basauri); y la lecluc, spara qué le van a comprar a Francia? (Orozco); La hierba... primero le he cortao, despuis le he dejao para que se seque ... y ahora vamos a recogerle (Arracundiaga): La vaca ... le ordeñas (Yurre) ; [...] eso blanco ... hay que quitarle después" ("/le (lu), la, lo (lu)/", art. cit., pág. 350 y nota 6 ).

73 Ya Maria Teresa Echenique sugirió que "en el castellano del País Vasco el leísmo de persona está extendido también al femenino, quizá como consecuencia de que no existe formalmente oposición de género en vasco" (Historia lingüistica vasco-románica, Madrid, Paraninfo, $1987^{2}$, pág. 100, nota 47). Encuentro esa dificultad en dominar el género igualmente en las equivocaciones en determinantes y adjetivos, por lo común a favor de la forma no-marcada, la masculina, y con sustantivos procedentes de la tercera declinación latina: "el sal, el sangre ( la sangre), el piel, el leche, el carne, el costumbre, el ikastola", "la orden de la casa", "la zanahoria, si quieres entero, y si quieres picar, picao". "la lana colgao pa secarse". "picar la piedra con unos hierros, ¿no?, con aquello picaba la piedra y [la] dejaba limpio y [la] colocaba otra vez", "tomate que ya está nacida". La indistinción afecta también a lo neutro: "el único picante" (lo único), "y el único d sabes lo que hacen?" (lo único), "lo ordinario se quedaba aquello pal ganao y el fino pa hacer pan" (la harina y el salvado). Ejemplos análogos a los de Apatamonasterio encuentro en Mundaca ("esas dos cosas hay pocos como aqui", "esos mantillas negras", "del mismo molino te traen ya quitao la cáscara y todo", "había uno que es más fino y el otro más, más ordinaria" (el maiz), "el menos peligroso" (lo menos), "lo de los domingos" (el [traje] de los domingos)) y en Galdácano ("una unión muy bárbaro", "la agricultura era esclavo", "la reúma". "la salvao", "mucho más educación que ahora"). 
plos de le acusativo con todo tipo de referentes, es lógico que la extensión se produzca preferentemente en lus contextos en que el referente es animado, y sobre todo, personal, ya que, según es sabido, es esa clase de argumentos la que recibe de modo casi exclusivo el caso dativo ${ }^{74}$. Veamos los escasos ejemplos ofrecidos por los informantes cuya habla se regia básicamente por el sistema (i) ${ }^{75}$ :

\section{Referente animado:}

Se suelta el cerdo, el carnicero le agarra de así; bueno, basta, Pedro, déjale, déjale ahi (a un hombre); pedir ayuda con la hermana, o la mujer o la*madre, lo que sea, llamarle pa atender a la gente; y le miro a ellas y les digo en vasco... (A pata); yo le crie con leche condensada (al hijo); yo, les crie yo (a sus hijos); a ésta le llevó la madre a Francia pa que no le viole nadie; ; si no podemos hacer esto! ; ni un "recao"!, le encontramos a la gente y no podemos venir a casa : y el salchichero te está esperando alli, le pone echao y i ya!... un gancho grande tiene asi, suele tener, $y_{i}$ tra! le [se lo] mete por aqui y ya se empieza a sangrar ... y luego pues, ya cuando deja el cuerpo, le llevan a las estas, a la paja. le queman y luego pues le cortan por en medio (el cerdo) (Mundaca).

Referente inanimado:

Yo tenia en Elorrio un piso pagándole; si, cuajo, eso. Y luego pues coger y meterle en un cacharro (Apata); si, cuando se está matando, pues una [la] está cogiendo y meneándole para que no se escape (la sangre): con traje negro casar y tenele yo pa toda la vida (Mundaca).

3. Cuando aumenta el conocimiento del castellano, aparecen tímidamente entonces los clíticos de acusativo masculino y femenino $l o(s)$ y $l a(s)$, más el neutro lo. Esos pronombres se abren camino en los contextos en que el referente es inaniniado (continuo o discontinuo), penetran parcialmente cuando es animado y nada si es personal. Las áreas de la animación y de lo personal

74 Ello explica la baja frecuencia del leísmo no-personal que registra Hernán Urrutia y que su porcentaje de aceptabilidad sea bajo ("El español en el País Vasco", art. cit., págs. 38-40). También debe relacionarse con este particular uso de los pronombres que se encuentra en zonas vascas o en contacto con el eusquera el empleo de le para acusativos de "cosa u objeto" que, seguin Antonio Llorente, existe en la mayor parte de La Rioja, desde el partido de Arnedo, cuenca del Cidacos, en I a Rioja Baja, hasta hacerse general en toda la región al occidente del río J.eza (“Algunas características lingüísticas de La Rioja en el marco de las hablas del valle del Ebro y de las comarcas vecinas de Castilla y Vasconia", RFE, XI.VIII, 1965, págs. 321-350, esp. 339-340), Que ese leismo descrito por Llorente ( $y$ que mis datos me impiden confirmar) es independiente de los sistemas referenciales castellanos nos lo asegura el hecho de que no coincide en la mayor parte de la región con el lcísmo personal, que sólo existe en el extremo occidental y asociado al laismo.

75 Los ejemplos proceden de Apatamonasterio y de Mundaca (Vizcaya). 
quedan, pues, reservadas preferente o exclusivamente a $l e, l e s^{76}$. El porcentaje de pronombres omiticlos sigue siendo tan o más elevado que el de presencias pronominales. Este particular uso parece representar el estadio siguiente en el aprendizaje del español ${ }^{n}$ :

le, les:

Porque estaba tan guapa, tan hermosa estaba, como pa mirarle (a una mujer); imi pobre madre, que ha salido pa que a la hija no le violen!; pero como a la madre no le dejaban [estar alli] ... y yo decia ¿la hija le va a dejar [abandonar] a la madre?; pocas [chicas] les veo yo [que coman cocido]; un altar precioso, que parece que a la Virgen le suben al cielo; con un gancho que le cogian ... y le hacian desangrar ... le agarran con un gancho por el cuello, le pone echao ahí, traen paja pa quemarle, le limpian con ladrillo, le raspan (al cerdo); y a la madrugada les tienes todavía sin venir a casa (a los jóvenes) (Mundaca); la última vez que le llevé, cuando le metí al cortijo (un toro); terneros o lo que sea, y a ellos habrá que matarles; ¿igual le mordería? (un cerdo a un niño); ha habido perro que al mismo dueño le ha mordido; el hernano mayor ... le levantaron ; a la mili!; ¿estamos bien educándoles a los niños?; al niño, hacerle más niño, más crío hoy en dia ni a un loco no le veo ni reir; el tercero... le mandé a Bilbao también (al hijo); le acompañabas a una chica, o le sacabas del baile (Galdácano).

$l o(s), l a(s):$

El tren ¿cuántos años hace que lo han puesto?; los pies te los solías lavar con lejia; para quemar el pellejo y quitarlo; ¿ el resto de la ropa? Nos la cosían; el maiz, cuando

76 Hasta hace poco no contabamos más que cun observaciones fragmentarias sobre estos usos, hecho que dificultaba su comprensión. Asi, el empleo de le para el objeto directo femenino, desconocido en los sistemas referenciales del occidente de Castilla, habia sido descrito como propio del castellano hablado en Vasconia, en gran parte de Navarra, extremo occidental de La Rioja, parte oriental de Cantabria y quizá las comarcas burgalesas del valle del Ebro (I.lorente, "Consideraciones", art. cit., pág. 25). Igualmente, en el Esbozo se dice que aparece en "escritores de origen no castellano, especialmente vascos" (Real Academia Española (Comisión de Gramática), Esbozo de una nucva gramática de la lengua española [1973]. Madrid, Espasa-Calpe, 1985, 2.2.2-3.). También lo encuentra Marcos en Baroja (Estudios solve el pronombrc, págs. 256-257). Sin embargo, no se había relacionado con las especiales características del lcismo vasco de objeto masculino. Sólo últimamente Hernán Urrutia ha caracterizado el sistema pronominal del romance hablado en el País Vasco como básicamente "etimológico" con la salvedad del empleo de le(s) como pronombre de acusativo cuando el referente es personal ("El español hablado en el País Vasco", art. cit., pág. 40). En cambio, María Jesús Korkostegi Aranguren condiciona ese empleo de le al carácter animado del referente (Pio Baroja y la gramática. Estudio especifico del leismo. laísmo y loísmo y la duplicación de objetos, San Sebastián, Universidad de Deusto, 1992, pág. 114), descripción que concuerda con los textos y los ejemplos de la lengua hablada recogidos en el castellano coloquial de los habitantes de Chorierri-Gran Bilbao por Mikel Zárate, que, sin embargo, no comenta explícitamente el fenómeno (Influencias del vascuence, op. cit., págs. 49, 65, 60, 115,104 , etc.).

${ }^{77}$ Los ejemplos proceden de informantes de Mundaca y Galdácano y debo su transcripción a Maria Jesús Diaz Orueta. 
lo cogiais ¿cómo haciais, pues?; pa salir gordo el caldo tienes que moverlo mucho (Mundaca): yo lo cogia por la soga y un palo, y lo llevaba (un toro); la orquesta hay que pagarla aparte: antes mil pesetas ; la madre del cordero! ¿cuándo las veias?; los cerdos los criabas; el pan, el trigo, tienes que triturarlo en molino; el arroz ... lo ponen en un eso y va cociendo lentamente; alguno que tiene en casa lo venderá (la leche); los que tienen ganao ahi, lo tienen que bajar para abajo, ... habrá hecho abajo chabolas o asi pa retirarlos (a los animales); el chorizo, pa ser calidad, lo tendrán colgao en los caserios; compras un poco carne ... y luego lo trituras y haces chorizo; la despedida ya lo haces con los intimos (Galdácano) ${ }^{78}$.

4. Conviene hacer notar que, suprimidos los pronombres de acusativo, no existe en esta zona de influencia eusquérica la secuencia de dativo + acusativo $m e, t e, s e+l o, l a, l o s$, las. En cambio, es posible encontrar se le en oraciones inipersonales, en las cuales le puede funcionar como clítico de acusativo (sigtiendo el uso propio de la zona) o de dativo:

$m c$, te, si + lo, la, los, las:

¿Costillas: Aquello le [se lo] quita el carnicero cuando va a partir el cerdo; el pecho casi todas le [se lo] daban; eso luego le deja el olor y esto no, no le [se lo] deja (al cerdo; pues aquello, el oscuro aquello le [se lo] quita la criba esa (el salvado a la harina) (Apata); hacer pedazos y darles [se los] con agua caliente (a los animales); esta pobre no tiene un vestidito, $\mathbf{y}$ a ver entre todos, a ver si le [se lo] hacen los hermanos; y las joyas que tenía la Dolorosa... pero le [se las] vendieron; el chorizo le [se lo] suelo cocer aparte y luego, a la final, pues le [se lo] echo ... la mitad del puerro le [se la] pico, la zanaloria le pico la mitad y en el crudo le echo la otra mitad (a las alubias) (Mundaca).

Y ellos te daban autorización para matar, pero ahora no te [la] dan; yo no sé quién me [lo] hizo, tampoco no me acuerdo, si me [lo] hizo mi madre o mi novia (el traje) (Apata); icon collar grande a mi casa! Me agarró el collar y me [lo] rompió (Mundaca).

Se le:

Datizo:

Se coge el sangre, una mujer está alli dando vuelta a la sangre, siempre se le da uno la vuelta y se le forma[n] unos hilos; y según está enfriando, hay que mover la leche, porque se le hace la nata, y pa que no se le hace la nata, mover [la] de vez en cuando; pa sembrar patatas y esas cosas se le daba vuelta a la tierra; se hacía con un palo grande y con dos pequeños, se les sacaba la punta (Apata).

28 Lo puede emplearse como pronombre de acusativo tanto con continuos como con discontinuos femeninos. Creo que ello debe ponerse en relación con las dificultades para dominar el género, y no verse como una posible prolongación del empleo astur-cántabro de lo referido a continuos femeninos. Véase cómo también en Ecuador y en Perú se prefiere lo como forma "comodín" de acusativo, evitando el manejo de la: Erica C. García, "Being polite in Ecuador", págs. 116-118, y "Bilingüismo e interferencia sintáctica", passim. 
Acusativo:

Allí se le atiende a la gente; se le agarra, se le echa encima la mesa, se le quita el piel (al cerdo) (Apata); a las viudas mal no se les ha mirao nunca; a la que más, así, más pobre se le ve (a una mujer); se le seca en la teca y luego con un palo pegar[les] (las alubias) (Mundaca).

5. El empleo de los pronombres átonos de tercera persona en el romance hablado por los monolingües castellanos en el País Vasco y en territorios vascófonos ha sido condicionado por el de los bilingües. Como fruto de esa secular convivencia lingüistica, su sistema pronominal se distingue del "etimológico" de las vecinas Aragón, Navarra y Rioja por una reorganización regional caracterizada por preferir le, les como pronombres de acusativo con referente animado ${ }^{79}$.

6. Los distintos sistemas de empleo pronominal que acabo de describir, propios de los territorios en que se da la coexistencia vascorrománica, han determinado el uso de la comarca de Las Encartaciones y del norte de la provincia de Burgos, esto es, la zona comprendida entre los ríos Asón (en Cantabria) y Trueba (en Burgos), al oeste; el Ebro, al sur; el Nervión, al este, y el Cantábrico, al norte. El interés fundamental de esta área, que podemos considerar de transición entre los sistemas vasco y cántabro, reside en el testimonio vivo que aporta a la comprensión de la génesis del sistema referencial. En ella el dativo y el acusativo singular coinciden con el sistema cántabro (con la salveciad de que el uso del acusativo le, aunque mayoritario, todavía compite con lo en la referencia a los discontinuos masculinos y de que la lucha con $l o$ en los continuos femeninos) ${ }^{80}$. El acusativo plural presenta, en cambio, una novedad de interés indudable respecto al sistema cántabro: la penetración de les, que lucha por desplazar a la forma "etimológica" los,

79 Aparte de suponerla muy difundida en las tres provincias vascas, es segura su vitalidad en el norte de Navarra. Véanse los mapas 1.712 (déjala en la cuadra), 1.713 (a la madre la vio en la calle), 1.715 (díselo) y 1.703 (a Miguel lo cogieron preso y lo llevaron a la cárcel) del vol. XII del Atlas Lingüístico y Etnográfico de Aragón, Navarra y Rioja, Madrid, La Muralla, Institución Fernando el Católico, CSIC, 1979-1983, 12 vols., de Manuel Alvar con la colaboración de Tomás Buesa y Antonio Llorente.

80 Ello coincide con los datos sobre el lo para no-contables aportados por García González: en Alava encuentra lo para no-contables en el ángulo noroeste (único explorado) en Arceniega y Menagaray; en Vizcaya en la comarca de Las Encartaciones en Carranza, Güeñes y Gordejuela, localidades todas ellas situadas al occidente del Nervión (“/le (lu), la, lo (lu)/”, art. cit., pág. 350). También resulta interesante advertir la semejanza de esta situación del noreste de Burgos con la que ofrece el sistema de transición suroriental. 
sobre todo cuando el referente es animado ${ }^{81}$. La presencia de les en el acusativo plural asociado a animados permite reconstruir las condiciones en que se produjo el avance de la indistinción que acabó desembocando en el sistema referencial castellano. Igualados el acusativo y el dativo singular en la forma le, la extensión de les al acusativo plural abrió la puerta a la confusión con referentes femeninos y continuos, dejó paso al laísmo y al loismo, en definitiva, a la creación del sistema referencial.

En fin, el empleo pronominal del romance hablado en el Pais Vasco y en su área vecina occidental también ayuda a comprender el porqué de la menor difusión del laísmo y del loísmo frente a la mayor del leismo.

\section{Distribución geográfica ACtuAl de LOS USOS REFERENCIALES.}

Aunque todavía es imposible precisar la exacta distribución geográfica de los diversos sistemas que acabo de describir, puede trazarse en lineas generales la isoglosa que separa las distinciones casuales de los varios tipos de confusiones o sincretismos pronominales ${ }^{82}$.

1. Al occidente, el límite discurre desde el Cantábrico remontando el curso del río Deva hasta sus fuentes ${ }^{83}$. Desde alli desciende por León siguien-

81 Les aparece también, aunque con frecuencia enormemente menor, en el acusativo plural femenino referido a animados. Reconstruyo este sistema de transición en Músquiz (Vizcaya), Menagaray, Turiso, Berganzo, Guinea (Alava), Trespaderne, Suzana, San Millán de San Zadornil, Castresana de Losa y Aostri (Burgos).

\begin{tabular}{|c|c|c|c|c|c|c|}
\hline \multirow{4}{*}{ ACUSATIVo } & \multicolumn{4}{|c|}{ SINGULAR } & \multicolumn{2}{|c|}{ PLURAL } \\
\hline & \multicolumn{2}{|c|}{ CONTABLE } & \multicolumn{2}{|c|}{ NO-CONTABLE } & \multirow[t]{2}{*}{ MASCULINO } & \multirow[t]{2}{*}{ FEMENINO } \\
\hline & masculino & femenino & masculino & femenino & & \\
\hline & le $(<10)$ & la & lo & la $(<10)$ & los $(<$ les $)$ & las \\
\hline DATIVO & le & le & & & le & \\
\hline
\end{tabular}

Conviene recordar que la frecuencia de les referido a animados es siempre superior a la de los alli donde ambas formas compiten por ocupar el plural masculino (tanto en el sistema (c) como con el área de transición del oriente de León). Ello debe relacionarse también con las observaciones tradicionales (Fernández Ramírez, Lapesa) que vinculaban el léismo a la creación de una distinción entre lo animado y lo inanimado en español.

82 Incluyo, pues, en el área confundidora los sistemas cántabro y de la zona vasca, así como las áreas de transición parcialmente referenciales, aunque, por supuesto, en estas zonas no se prescinde del caso al establecer la referencia pronominal del mismo modo que en el área plenamente referencial.

ss De acuerdo con mis datos, participan del sistema cántabro (h) Colombres, Lebeña, Mogrovejo, Ledantes, Frama y Valdeprado (Cantabria), mientras que Arenas de Cabra- 
do al río Esla, desde su nacimiento en Riaño hasta que deja atrás la cordillera Cantábrica a la altura de Cistierna ${ }^{2}$. La isoglosa gira entonces hacia occidente englobando los valles bajos de los ríos Porma, Curueño y Torío, mientras que en los valles altos de esos ríos, en la montaña leonesa, se mantienen las distinciones casuales ${ }^{85}$. Desde León el limite continúa descendiendo hacia el sur coincidiendo con el Bernesga, primero, y el Esla, después, hasta alcanzar Benavente ${ }^{86}$. Desde alli la frontera discurre dejando fuera la totalidad de la provincia de Zamora ${ }^{87}$, salvo la esquina oriental, a la derecha de la carretera nacional VI entre Benavente y Tordesillas, zona que pertenece a Tierra de Campos ${ }^{88}$. La linea continúa paralela y a poca distancia de la frontera con Zamora ${ }^{89}$, hasta que vuelve a penetrar en esta provincia por el extremo inferior derecho en algunos pueblos ribereños del río Guareña ${ }^{90}$. En

les y Parres (Asturias) emplean el sistema (f) y Alles, Para (Asturias) y Linares (Cantabria) emplean la modalidad (g) en competencia con el tipo (h). La frontera lingüística puede, por tanto, ser una más de las isoglosas que separan el bable y las hablas cántabras formando el límite señalado por Francisco García González, "La frontera oriental del asturiano", $B R A E$, LXII, 1982, págs. 173-191, y "La frontera oriental del asturiano: razones históricas de su fijación", Archivrem, XXXI-XXXII, 1981-82, págs. 337-354.

* Son referenciales Boca de Huérgano, Besande, Prioro, Aleje, mientras que Las Salas, Lario y Reyero (León) son "etimológicos"

ss Son "etimológicos" Lorenzana, Santibáñez, Geras, Cármenes, Pardavé y Lugueros. Referenciales Manzaneda de Torío, Santa Colomba de Curueño, Palazuelos de Boñar, San Cipriano del Condado y Cifuentes, Quintanilla y Cubillas de Rueda.

86 Distinguen Mozóndiga, Cembranos, Villagallegos y Laguna de Negrillos, y confunden Villasabariego, Villarmún, Cubillas de los Oteros, Villafer y Valderas. Véase también Santiago Alonso Garrote (El dialecto vulgar salmantino hablado en Maragatería y tierra de Astorga. Notas gramaticales y vocabulario, Madrid, CSIC, 1947², página 98), que tampoco encuentra leismo.

${ }_{87}$ Según mis datos son "etimológicos" San Cebrián de Castro, Granja de Moreruela, Arquilinos, Villalba de Lampreana, Malva, Pinilla de Toro, Venialbo y Villamor de los Escuderos. Estas conclusiones se confirman por las de Antonio Llorente, que no encuentra ninguno de los usos referenciales en Espadañedo, Brime de Sog, Pozuelo de Tábara, Andavías, Fermoselle, Belver de los Montes ni en Venialbo ("Las hablas vivas de Zamora y Salamanca", art. cit., pág. 128). El análisis de los textos dialectales recogidos por Fritz Krüger (El dialecto de San Ciprián de Sanabria, Madrid, Centro de Estudios Históricos, 1923, Anejo IV de la $R F E$, págs. 111-117) arroja el mismo resultado. Lo mismo dice Antonio Llorente de la Ribera de Duero salmantina (Estudio sobre el habla de la Ribera, Salamanca, CSIC, 1947, págs. 162-163).

88 Encuentro el sistema referencial en Prado y Cotanes, lo que corrobora lo dicho por Llorente sobre Cerecinos de Campos ("Las hablas vivas", art. cit., pág. 127). La frontera cruza justo en ese punto: mientras que Prado participa del sistema referencial, en Villalobos, 4 kilómetros hacia occidente, el sistema pronominal es básicamente "etimológico", con alguna penetración referencial leísta y laísta.

a Son "etimológicos" en Valladolid Castromembibre y Casasola de Arión, aunque en este último encuentro ya penetración de los empleos referenciales. Cabreros del Monte, Pozuelo de la Orden, San Cebrián de Mazote, La Mota del Marqués, Villalar de los Comuneros y Castrejón son, en cambio, básicamente referenciales.

90 Llorente documenta leísmo y laísmo en Vadillo de la Guareña (Zamora) y, en el margen del mismo río, en Tarazona de la Guareña (Salamanca) ("Las hablas vivas", art. cit., pág. 127). 
Salamanca la isoglosa coincide primero con ese rio, enlaza con el Tormes a la altura de Alba y sigue su curso hasta llegar a Béjar. Asi, sólo la franja oriental de Salamanca comprendida entre el Tormes y el limite con Ávila ofrece usos referenciales, los cuales se hacen más sistemáticos según se avanza hacia oriente ${ }^{91}$. Desde Béjar la línea desciende coincidiendo con la carretera de Plasencia, la antigua calzada Guinea o Ruta de la Plata, que separaba la Extremadura leonesa (al oeste de la calzada) de la castellana (al este) ${ }^{92}$. Por lo que sé hasta ahora, hay usos referenciales en la franja oriental de Cáceres ${ }^{93}$ y todavía en el extremo nororiental de Badajoz, en Herrera del Duque ${ }^{\text {, }}$, territorio cuya reconquista también correspondió a Castilla. La frontera debe, por tanto, coincidir con la línea imaginaria que une Plasencia con Trujillo y Herrera del Duque. Ni el astur-leonés ni los territorios sujetos a su influencia lingüística, pues, son confundidores, salvo en las franjas orientales de León, Salamanca y Cáceres. Quizá la idea de que la confusión estaba extendida en León, además de en Castilla, provenga de mezclar ejemplos procedentes de esas zonas orientales con los del resto de las provincias 95 .

2. Desde Herrera del Duque la línea que separa los usos distinguidores de los confundidores avanza aproximadamente sobre el límite entre Toledo y Ciudad Real, que divide las dos laderas de los Montes de Toledo. Mientras que al norte de esos Montes el sistema es referencial, al sur es básicamente

91 Según mis datos, no mantienen las distinciones de caso Tarazona de la Guareña, Poveda de las Cintas, Tordillos, Alba de Tormes, Cespedosa ni Santibáñez de Béjar. Son básicamente "etimológicos", con alguna vacilación, Ejeme, Siete Iglesias de Tormes y La Maya. Distinguidores son Puebla de Yeltes, Berrocal de Huebra, Sotoserrano, Endrinal, Valdelacasa, Membibre, Berrocal de Salvatierra y San Pedro de Rozados. Mis datos coinciden con los de Llorente ("Las hablas vivas", art. cit., pág. 128), que asegura como "etimológicos" a La Vídola, Vilvestre, Navasfrias, El Saúgo, Alba de Yeltes, Monsagro, Ciṕ́rez, Villavieja, Herguijuela, Linares, Carrascal del Obispo, Rollán, Palacios del Arzobispo, El Cerro, Pedrosillo de los Aires y Villaverde de Guareña, y como "referenciales", a tres localidades próximas a Ávila: Pedraza de Alba, Aldeaseca de la Frontera y Santibáñez de Béjar.

92 Son confundidores Villar de Plasencia y Jarilla, a la derecha de la calzada, y distinguidores Aceituna y Santibáfiez el Bajo, a la izquierda.

93 En Castañar de Ibor y Navalvillar de Ibor encontramos con plena vigencia el sistema (b). En Torrecilla de la Tiesa, se mezcla ya el sistema (b) con los usos "etimológicos".

9 En Fuenlabrada de los Montes, junto a Herrera, existe el sistema (b) en retroceso ante las distinciones casuales; unos pocos kilómetros más al sur, en Peñalsordo, el sistema es el "etimológico" con la salvedad del empleo minoritario (20\%) de le como acusativo para entes masculinos contables.

95 Véanse Cuervo, "Los casos", pág. 233; Ramón Menéndez Pidal, El dialecto leonés [1906], León, Diputación Provincial, 19903, pág. 60; Robert K. Spaulding, "Is accusative le only castilian or northern too?", Hispanic Review, XIII, 1945, págs. 336-340, esp. pág. 336, y Lapesa, “Sobre los orígenes”, pág. 527. 
"etimológico" \%. La isoglosa se prolonga englobando el este de Toledo y la franja occidental de Guadalajara ${ }^{n}$, y continúa subiendo hacia el norte por Soria, desgajando el partido occidental del Burgo de Osma de los orientales y "etimológicos" de Soria y Agreda ${ }^{9}$. Coincide primero con el curso del río Caracena y se prolonga hacia el norte siguiendo el rio Ucero, primero, y el río Lobos, después ${ }^{9}$. Desde Salas de los Infantes sube hacia Belorado, y de alli parece penetrar en La Rioja siguiendo el cauce del río Tirón, hasta que desemboca en el Ebro a la altura de Haro, desmembrando la esquina noroccidental del resto de la provincia ${ }^{100}$. El límite gira entonces hacia el este y,

* En Toledo participan del sistema referencial (b) los pueblos de Cerralbos, Caleruela, Arisgotas, Los Navalucillos, La Nava del Ricomalillo, Villarejo de Montalbán, La Pueblanueva y Buenasbodas (y según ha tenido la amabilidad de comunicarme KleinAndreu, también Nambroca, Huerta de Valdecarábanos y El Casar de Escalona). En cambio, Casas del Río (con mínima introducción de le en el área del acusativo masculino personal), Torrenueva, Las Labores y Almadén (Ciudad Real) son distinguidores.

97 En esta área oriental de Toledo y occidental de Guadalajara el uso pronominal responde a los parámetros del sistema de transición suroriental (c), cmpleado en los enclaves citados en la nota 50 . Fuera del área del sistema de transición, los usos pronominales son básicamente "etimológicos" aunque todavía pueden encontrarse casos de leismo para acusativo masculino singular personal (en porcentaje muy minoritario) en Cincovillas, Hortezuela de Océn, Castilmimbre (Guadalajara), La Frontera y Osa de la Vega (Cuenca). Son "etimológicos" absolutos Corral de Almaguer (Toledo), Alboreca y Mochales (Guadalajara). El uso es también "etimológico" en La Roda (Albacete) (véase Chacón Berruga, El habla de La Roda, op. cit., págs. 252-253). La frontera entre el sistema referencial de tipo (b) y el sistema de transición suroriental (e) parece discurrir hacia el norte, coincidiendo con el límite oriental de los Montes de Toledo, y continuarse en dirección a Toledo capital: Consuegra, Madridejos, El Romeral, Lillo, Camarenilla y Recas son transicionales, mientras que Arisgotas, Los Cerralbos, El Casar de Escalona, Nambroca y Huerta de Valdecarábanos son referenciales. No es evidente, pero parece que el limite avanza hacia el norte en dirección ligeramente desviada hacia el este y penetra en Madrid a la altura de Aranjuez, hecho que explicaria la vigencia del sistema (b) en el noroccidente de la provincia: en Navalafuente, Bustarviejo, Lozoya, Horcajo y Montejo de la Sierra.

${ }_{28}$ Ese trazado, que avanzó en su dia Klein-Andreu (“Factores sociales”, pág. 59), queda ratificado por los datos recogidos en nuestras encuestas.

$\infty$ Según mis propios datos, son referenciales Villacorta (Segovia), Fuentecambrón, Morcuera, Tarancueña, Villálvaro, Valdemaluque, La Hinojosa (Soria) y Coruña del Conde (Burgos). Distinguidores son Brias, Fuentepinilla, Cubilla (Soria) y Canicosa de la Sierra (Burgos).

100 De acuerdo con mi información, Vizcainos, Jaramillo de la Fuente, Cabañas de Juarros, Villasur de los Herreros, Quintanaloranco, Quintanabureba (Burgos), Herramélluri y Sajazarra (La Rioja) son referenciales, mientras que Zorraquín, Manzanares de Rioja, Zarratón, Ledesma de la Cogolla y Briones (La Rioja) son "etimológicos". Ello coincide con lo anotado por Llorente sobre los usos pronominales en La Rioja ("Algunas características lingüísticas", art. cit., págs. 339-340). Según ese autor, existe lefsmo personal, de cosa u objeto, y laismo en Tormantos, Casalarreina y Bugedo, mientras que el leismo de persona alterna ya con el uso "etimológico" en Alesanco y San Asensio. En Albelda y Valgañón no existe ya leismo personal. El río Tirón aísla, pues, a los tres pueblos, en el occidente de la región, del resto. Véase asimismo el mapa 1.711 del $A L E A N R$, XII, de Alvar, que muestra laismo en Bugedo (Burgos), Casalarreina, 
tras avanzar sobre el cauce del Ebro hasta Logroño, que separa a La Rioja de Alava, penetra en Navarra prosiguiendo en dirección noreste hacia Estella, Pamplona y Roncesvalles ${ }^{101}$.

3. La desembocadura del Deva, al oeste, y Roncesvalles en el Pirineo navarro, al este, parecen ser los puntos limítrofes septentrionales de los usos pronominales no-"etimológicos". El sistema referencial propiamente dicho no se da, sin embargo, a lo largo de esa franja cántabro-pirenaica, dominada por el sistema pronominal cántabro y el propio del romance hablado en la zona vascófona. Para encontrarlo hay que desplazarse al sur de la cordillera. El limite septentrional que separa el área referencial castellana, plenamente confundidora, de los sistemas de empleo pronominal vecinos, cántabro y eusquérico, discurre desde Haro remontando el curso del Ebro hasta llegar a sus fuentes ${ }^{102}$. Desde Reinosa la frontera avanza hasta Riaño coincidiendo con la división administrativa entre Cantabria y Palencia ${ }^{103}$, y desde alli, según ya dijimos, comienza a descender hacia el sur acompañando al Esla.

\section{Conclusión.}

La distribución geográfica de los distintos sistemas de empleo pronominal no-"etimológico" nos conduce, como núcleo originario de la confusión entre el dativo y el acusativo, a la región de la Castilla primitiva: la Cantabria meridional y las zonas circunvecinas de los valles altos del Pisuerga y del Ebro.

\footnotetext{
San Asensio y Tormantos (La Rioja), asi como el 1.708, que ofrece leismo para persona masculina en esos puntos además de en Canales, Viniegra de Arriba y Valgañón.

101 Según la distribución geográfica del particular leísmo propio del romance hablado en zona vascófona que puede deducirse de los mapas 1.708, 1.712, 1.713 y 1.715 del ALEANR, XII (véase supra, nuestra nota 79). Si tomamos como muestra del discurrir de la frontera el 1.713 (a la madre $l a$ vio en la calle), Eulate, Zudaire, Salinas de Oro, Pamplona, Añorbe, Erro, Egozcue y Espinal marcan el área leista, mientras que Aguilar, Allo, Estella, Berbinzana, San Martín de Unx, Monreal, Artieda, Garayoa y Ochagavía la zona distinguidora.

103 Al norte del Ebro no son referenciales (no hay laismo ni loísmo), Turiso, Berganzo (Âlava), Suzana, Barcina del Barco, San Millán de San Zadornil, Trespaderne, San Cristóbal de Almendres, Quintana de los Prados y Quintanilla de Baldebodres (Burgos). Al sur del Ebro encuentro en funcionamiento el sistema referencial en Barcina de los Montes, Salas de Bureba, Gredilla de Sedano y Abajas.

103 Mientras que en la vertiente sur de la cordillera son referenciales Montoto de Bezana, Arreba, Orbaneja del Castillo, Covanera, Virtus, Herbosa (Burgos), Ruanales, Arroyal, Reinosa, Mata de Hoz (Cantabria), Santa María de Nava, Ligüerzana, San Salvador de Cantamuda, Santibáñez de Resoba, Alba de Cardeñosa, Roscales de la Peña, Muñeca (Palencia), Besande, Boca de Huérgano y Prioro (León), en la vertiente norte emplean el sistema cántabro, Portillo de la Reina (León), Ledantes, Mogrovejo, Frama, Valdeprado, Tudanca, Cosío, Silió y San Vicente de Toranzo (Cantabria).
} 
Es precisamente en esa zona donde encontramos que el sincretismo pronominal cántabro entre el acusativo y dativo singular masculino en $l e$ se acompaña de la extensión de las formas acusativas la, las y $l o$ al dativo y de la de les al acusativo masculino, dando luz al sistema referencial castellano.

El uso pronominal de las áreas inmediatamente vecinas astur-cántabra y vascófona nos permite comprender el proceso de creación de ese sistema como la sintesis resultante del contacto lingüistico entre individuos venidos del norte cántabro y del este eusquérico.

1. La aparición del sincretismo de dativo y acusativo en la forma le en el centro y oriente cántabro debe de tener su origen en el contacto secular de esos territorios con el área vascona situada al oriente, influencia que corroboran otros fenómenos como la aspiración de la $\mathrm{F}$ - inicial latina ${ }^{104}$. Para explicar que la oposición continuo/discontinuo, que venía funcionando en los distintos bables de la Asturias centro-oriental y en el occidente de Cantabria, sustituyera las formas usuales $l u \sim l o$ del acusativo masculino por el pronombre le se ha recurrido al argumento de que la distinción entre continuos y discontinuos se veia puesta en peligro por la tendencia general al cierre de las vocales átonas finales, que habría hecho confluir $l u$ con $l o>l u{ }^{105}$. Pero creo además que hay que relacionar ese cambio con otras razones de carácter histórico. Cantabria es un territorio sometido a una doble influencia lingüistica, la del dialecto astur-leonés por el oeste y la del vasco por el este. Según sea más fuerte uno u otro influjo, pueden distinguirse dos zonas lingüísticas: la Cantabria norteña y occidental, que continúa rasgos lingüísticos del oriente asturiano, y la levantina y meridional, con fuertes lazos políticos, culturales y económicos con las regiones del este más o menos vasconizadas ${ }^{106}$. Esas circunstancias históricas no deben olvidarse para comprender la génesis del sistema pronominal cántabro. Si el establecimiento de marcas gramaticales que permitieran distinguir en la referencia los entes continuos de los discontinuos es de origen astur-leonés ${ }^{10}$, la sustitución de la forma leonesa $l u$ por le debe

10 Véase Lorenzo Rodríguez Castellano, "Estado actual de la h- aspirada en la provincia de Santander", Archivrom, IV, 1954, págs. 435-457, y Penny, "Esbozo de un Atlas", art. cit., págs. 157-158.

100 Véase supra, nota 61.

106 Esta división ha sido señalada por Emilio Alarcos y se deja entrever perfectamente en la distribución de condados de la antigua Cantabria: "Pensemos solamente que las tierras norteñas de Cantabria se llamaron Asturias de Santillana, Asturias de Trasmiera y hasta Asturias de Laredo; pensemos en las relaciones de la Liébana con los condados palentinos del sur; pensemos en que Campó abarcó la comarca de Reinosa y Aguilar; pensemos en que los pasiegos se sentían diferentes de los montañeses y se desplazaban más a la burgalesa Espinosa de los Monteros que a Carriedo, etc." (El español, lengua milenaria (y otros escritos castellanos), Valladolid, Ámbito, 1989, pág. 77).

107 Hoy parece demostrado que la oposición continuo/discontinuo (con su rasgo asociado, la metafonía) funciona en plena vigencia en un área ininterrumpida que se extien- 
haber sido favorecida por la influencia del eusquera, pues, según hemos visto ${ }^{106}$, el romance hablado por vascófonos ofrece la particularidad de extender al acusativo la forma dativa $l e$, especialmente si el referente es animado, por la dificultad que entraña para esos hablantes el dominio del género ${ }^{109}$.

Dado que la probabilidad de préstamo de las categorias gramaticales disminuye según aumenta la complejidad de sus funciones sintácticas ${ }^{110}$, es necesario aclarar el porqué y el cómo de la reinterpretación del pronombre le. Me parece evidente que la causa de ese reanálisis fue la mala comprensión del sistema de referencia pronominal que regia el romance hablado por vascos ${ }^{11}$, incomprensión que hubo de tener lugar en aquellos contextos sintácticos en que un argumento aparentemente referido por le sólo podia recibir, para el hablante del astur-leonés oriental, caso acusativo. Forman parte de ellos no sólo frases del tipo "se suelta el cerdo, el carnicero le agarra de asi", "yo le crie con leche condensada" (al hijo) o "con traje negro casar y tenele yo pa toda la vida", en que un argumento masculino y discontinuo en posición acusativa se ve referido por $l e$, sino también otras como "esta pobre no tiene un vestidito, y a ver entre todos, a ver si le [se lo] hacen los hermanos", "y luego el hígado, la cocinera se prepara, le [se lo] cogen entre todos", "luego, un pedazo de lomo se le da al veterinario pa que pruebe si está bien de salud o mal y cuanto más grande le [se lo] das, mejor para el veterinario" o "el primer piso, aquello compré con trece mil pesetas, y luego, el inquilino que tuvo aquí no quiso salir, que le vendamos aquello, y nosotros, como esto nos convenía más, pues le [se lo] vendimos por una porquería". En este segundo grupo le es un pronombre de dativo para el hablante vascófono de romance pero el interlocutor astur-leonés lo entiende necesariamente como acusativo,

de desde el río Nalón hasta el oriente de Cantabria, contra lo que creyó Menéndez Pidal, que pensó en una repoblación del Valle del Pas por gentes venidas de Asturias: véanse Neira, “La oposición 'continuo/discontinuo'”, art. cit., págs. 264-266, y Ramón Menéndez Pidal, "Pasiegos y vaqueiros. Dos cuestiones de geografía lingüística", Archivum, IV, 1954, págs. 7-44, esp. pág. 18.

108 Véase supra, V.

100 Hay que destacar que en algunos territorios donde el español convive con otras lenguas no-indoeuropeas, como el quechua y el guaraní, se produce la misma sustitución. Véase Fernández-Ordóñez, "Leísmo, laísmo y loísmo", art. cit., págs. 87-90.

110 Véase Arnulfo G. Ramírez, El español de los Estados Unidos. El lenguaje de los hispanos, Madrid, Mapfre, 1992, págs. 188-192.

111 En este sentido, considero reveladoras las palabras de Erica C. García: "Todo cambio gramatical depende, en última instancia, de un malentendido. Pero un malentendido, por definición, constituye una falla comunicativa, y el cambio lingüístico sólo puede cundir si el malentendido inicial pasa inadvertido, o sea, si es comunicativamente inocuo. Un malentendido 'serio' - que se reconozca como tal- no prosperará como cambio lingüístico. El oyente que advierta que su interpretación es incorrecta volverá, necesariamente, al valor original de la forma" "Sincronización y desfase", art. cit., pág. 248). 
ya que la presencia previa del argumento referido hace obligada su duplicación por el pronombre ${ }^{112}$.

Estas circunstancias sintácticas no explican, sin embargo, por qué la reinterpretación de le se dio exclusivamente con referentes masculinos y discontinuos, ya que, según hemos visto (cf. V.2-4), le también puede referir a argumentos femeninos y continuos, tanto cuando es lativo como cuando cumple la referencia acusativa. El reanálisis de le tuvo que ser limitado necesariamente por otro factor, la continuidad o discontinuidad del referente y su género. Frente a la indiferencia por esas distinciones manifiesta en el romance hablado por vascos, el que utilizaban los astur-leoneses les otorgaba gran importancia, manifestándolas no sólo en los pronombres átonos sino en los tónicos y en los adjetivos. De ahí que frases como "aquello, el oscuro aquello le [se lo] quita la criba esa" o "a esta le llevó la madre a Francia pa que no le viole nadie”, en que los pronombres tónicos aquello y esta están señalados claramente por la marca de la continuidad y del femenino no podían entenderse sin gran dificultad como referentes de le. El hablante astur-leonés hubo de reconocer el carácter foráneo de esas frases, hecho que impidió su adopción.

2. La creación del sistema cántabro originó el sincretismo de la forma le, pero no implicó la confusión del acusativo con el dativo tal como aparece en el sistema referencial castellano. Para explicar cómo se produjo esa confusión, no hay que olvidar el área en que la vemos emerger funcionando al sur de la cordillera cantábrica: el noroeste de Burgos, el norte de Palencia y el sur de Cantabria. Justamente esa zona fue la Castilla Vieja primitiva y en ella se

112 En "a Juan le vi" o en "el libro le devolvi" un hablante de español interpreta necesariamente le como pronombre de acusativo que refiere a los argumentos externos "Juan" y "el libro". Sin ese pronombre, esas frases son agramaticales "*a Juan vi", " "el libro tengo". Es imposible que le se interprete en estas frases como forma dativa porque si en cualquiera de ellas existiese además un argumento que recibiese caso dativo (por ejemplo, "le vi el coche nuevo a Juan", "le devolvi el libro a María"), su pronominalización exige siempre su coaparición con el argumento que recibe caso acusativo: o bien el dativo le acompaña a un argumento nominal pleno, o bien el pronombre de dativo se se acompaña del de acusativo, lo (en zona "etimológica") o le (en zona referencial). En cambio, en el romance hablado por vascos la secuencia se $+l o$ no existe y "a Juan le vi", "el libro le devolvi" representan la forma habitual de pronominalizar "a Juan le vi su coche nuevo" y "le devolví el libro a María". La probabilidad de incomprensión de estas frases con el argumento situado en posición preverbal es muy alta, ya que una de las características más acusadas del romance hablado por vascos es la anteposición de los complementos al verbo. Como ejemplo, véanse estas frases recogidas en Galdácano y Mundaca: "unos 37 ańos hará", "en el taller mecánico trabajo", "en el fuego bajo pones", "las galletas María pasteles eran", etc. Ello se debe a que en vasco el orden sintáctico está al servicio del foco del discurso, de modo que el elemento focalizado aparece situado en la primera posición: cf. H. Urrutia, "El español en el País Vasco", art. cit., págs. 35-36. 
gestaron los rasgos castellanos esenciales en una nivelación lingüistica entre individuos venidos del oeste leonés, del este eusquérico y del norte cántabro ${ }^{113}$. La reconocida importancia de la presencia de individuos de habla vasca ${ }^{114}$ creo que permite alumbrar la génesis del sistema referencial a través del testimonio que hoy nos aporta tanto el romance hablado en las áreas bilingües como el de las comarcas monolingües de Las Encartaciones y del noreste de Burgos, que no siempre pertenecieron a Castilla. En esos territorios la presencia de $l e$ en el acusativo masculino singular se acompaña de la de les en el plural. La reinterpretación de les como pronombre acusativo de plural masculino hubo de darse no sólo a partir de frases como "¿estamos bien educándoles a los niños?" o "les crie yo" (a sus hijos), en que les ocupa una posición acusativa, sino tambièn a partir de otras como "hacer pedazos y darles [se los] con agua caliente" (a los animales), en que les cumplia funciones de dativo en el peculiar romance de los vascos, pero se entendía como acusativo por parte de los interlocutores monolingües románicos. $\mathrm{La}$ igualación del acusativo y del dativo en el masculino desencadenó indudablemente el mismo fenómeno en el femenino y cuando el referente era continuo, originando el sistema referencial.

3. Mientras que el leismo consiste en la extensión de las formas del dativo al acusativo, el laismo y el loismo es el proceso inverso, la eliminación de los pronombres de dativo a favor de los de acusativo. Esta disimetría puede explicarse recurriendo a la diversidad de origen de uno y otros fenómenos. El leismo fue posible por la carencia de pronombres de acusativo en la modalidad románica hablada por vascófonos; en cambio, el laismo y el loismo fueron fruto del deseo de mantener las distinciones sintácticas de género y entre lo continuo y lo discontinuo, consideradas de gran importancia, en vista de que las de caso empezaban a ser destruidas (o lo habían sido ya) por la reinterpretación de los valores de le, les como formas pronominales masculinas y discontinuas con independencia de su posición sintáctica. Ello aclara asimismo la sucesión cronológica y la distribución geográfica de estos fenómenos, encajando con las observaciones tradicionales. El leismo tuvo que ser previo al laismo y al loismo, y se da con exclusión de las otras dos confusiones en el área cántabra porque en la variedad lingüística románica alli empleada el

113 Véase Menéndez Pidal, Origenes del español. Estado lingüístico de la Penírsula Ibérica hasta el siglo XI, Madrid, Espasa-Calpe, 1980, págs. 472-473.

114 Siguiendo a Pidal, recuerda Alarcos que "no debemos olvidar la fuerte repoblación de origen vascongado que se produjo en la Edad Media (si no antes) por las tierras del alto Ebro y del norte de Palencia, reflejada en topónimos tan reveladores como $V i$ llabáscones, Báscones, Basconcillos, Bascur̃ana, etc., y la documentada presencia del vascuence hasta cerca de Burgos desde La Rioja occidental en aquellos siglos" ( $o p$. cit., pág. 78). 
sincretismo de dativo y acusativo en el pronombre le no llega a amenazar las oposiciones sintácticas de caso hasta el punto de que peligre el establecimiento de la referencia pronominal.

4. La distribución geográfica del sistema referencial (en sus distintas variantes) está claramente relacionada con la expansión castellana (y no con la leonesa). Asi, por ejemplo, la existencia de usos referenciales en el extremo occidental de La Rioja tiene sus causas históricas en la pertenencia a Castilla de esos territorios desde el siglo $\mathrm{x}^{115}$. Igualmente, la línea que separa los usos distinguidores de los confundidores coincide significativamente con los límites de los territorios reconquistados hasta finales del siglo xı. Pero mientras no delimitemos exactamente la extensión de cada uno de los subsistemas referenciales, es muy arriesgado sacar conclusiones sobre su antigüedad en los varios territorios castellanos ${ }^{116}$. En este sentido, la interpretación correcta del testimonio aportado por las áreas de transición creo que será fundamental para comprender el proceso expansivo de los usos confundidores.

No obstante, la combinación de la geografía lingüistica con la historia probablemente no baste para aclarar por qué el sistema referencial no ha alcanzado mayor extensión. Las causas por las que no se difundió por todo el reino, justo al contrario de lo que sucedió con otros cambios norteños, como el reajuste fonológico que conduce al español moderno, deben buscarse en el hecho de que los sistemas sintácticos, en contraste con las unidades léxicas o fonéticas, son mucho más raramente adoptados por hablantes ajenos a ellos. $\mathrm{La}$ inexistencia del sistema referencial fuera de Castilla prueba lo improbable de que se presten aquellos elementos que pertenecen al núcleo de la gramática.

Nota final: Ya en prensa este artículo he tenido conocimiento del último trabajo de F. Klein-Andreu, Deixis over Anaphora: The Reanalysis of the Spanish Third-Person Clitics, presentado en The Conference on Anaphora, University of Colorado, en mayo de 1994. En él Klein ofrece una interesante comparación estadística de sus datos de Valladolid (sistema a) con los de Soria (empleo “etimológico”), norte de Toledo (sistema b) y sur de Toledo (sistema de transición suroriental). panorama que coincide básicamente

115 “E1 conde de Castilla, Fernán González, lo mismo que sus sucesores, poseian la parte más occidental de La Rioja, hasta Grañón y Pazuengos inclusive, a 4 kilómetros del monasterio de San Millán. Después toda La Rioja se incorporó a Castilla", según recuerda Menéndez Pidal, Origenes del español, op. cit., pág. 469.

${ }_{116} \mathrm{Hay}$, asimismo, un uso referencial del que apenas he documentado muy pocos ejemplos de la lengua hablada y del que ignoro si está relacionado con algún subsistema referencial concreto: se trata del loismo singular con referentes masculinos (no-neutros). Parece ser uso muy minoritario y propio de gentes incultas en todas las épocas (véase Lapesa, "Sobre los orígenes", págs. 547-548). 
con nuestras impresiones. Partiendo del analisis de esas zonas, defiende que la evolución desde el sistema "etimológico", el más antiguo, hasta el sistema de Valladolid, que juzga el mas moderno, habria pasado por los grados intermedios que representarian los datos de Toledo, mediante reanálisis sucesivos de los rasgos pertinentes en el establecimiento de la referencia pronominal. Aunque esta interpretación no me convence plenamente, hay que señalar que sólo después de reexaminar históricamente el empleo pronominal átono sobre nuevos parámetros de análisis se podrán despejar definitivamente las dudas sobre su génesis y evolución. 


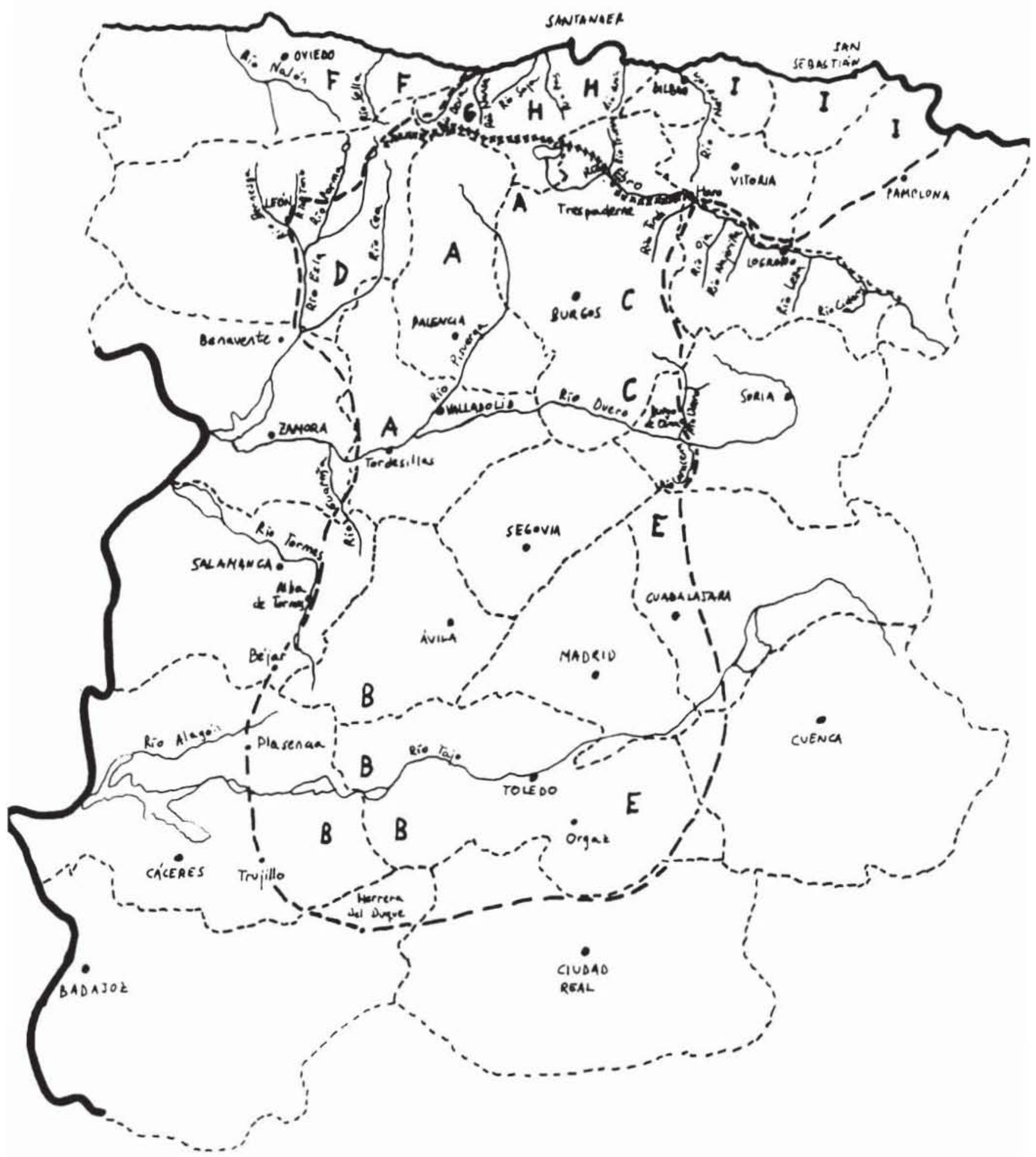

Los distintos sistemas de referencia pronominal no "etimológicos". Limite de los sistemas de referencia pronominal no "etimológicos". xxxxx: Límite septentrional del sistema referencial. 